Maurer School of Law: Indiana University

Digital Repository @ Maurer Law

\title{
An Empirical Analysis of Lateral Lawyer Trends from 2000 to 2007: The Emerging Equilibrium for Corporate Law Firms
}

\author{
William D. Henderson \\ Indiana University Maurer School of Law, wihender@indiana.edu \\ Leonard Bierman \\ Texas A \& M University - College Station
}

Follow this and additional works at: https://www.repository.law.indiana.edu/facpub

Part of the Business Organizations Law Commons, and the Legal Profession Commons

\section{Recommended Citation}

Henderson, William D. and Bierman, Leonard, "An Empirical Analysis of Lateral Lawyer Trends from 2000 to 2007: The Emerging Equilibrium for Corporate Law Firms" (2009). Articles by Maurer Faculty. 461.

https://www.repository.law.indiana.edu/facpub/461

This Article is brought to you for free and open access by the Faculty Scholarship at Digital Repository @ Maurer Law. It has been accepted for inclusion in Articles by Maurer Faculty by an authorized administrator of Digital Repository @ Maurer Law. For more information, please contact rvaughan@indiana.edu. 


\title{
An Empirical Analysis of Lateral Lawyer Trends from 2000 to 2007: The Emerging Equilibrium for Corporate Law Firms
}

\author{
WILLIAM D. HENDERSON* \& LEONARD BIERMAN**
}

TABLE OF CONTENTS

INTRODUCTION. . . . . . . . . . . . . . . . . . . . . . 1396

I. Summary of Data. . . . . . . . . . . . . . . . . . . 1399

A. LAWYER LATERAL MOVEMENT . . . . . . . . . . . . . . 1399

B. THE AM LAW $200 \ldots \ldots \ldots \ldots \ldots \ldots \ldots$

II. ANALYSIS OF LATERAL MobILITy TRENDS . . . . . . . . . . . 1403

A. GEOGRAPHIC TRENDS . . . . . . . . . . . . . . 1403

B. FIRM SIZE, STRUCTURE, AND PRÖFITABILITY. . . . . . 1406

C. LATERAL MOVEMENT BY PRACTICE AREA. . . . . . . . . 1411

D. LAW FIRM MOBILITY AND GOVERNMENT AND PRIVATE INDUSTRY EMPLOYMENT . . . . . . . . . . . . . . 1417

III. Discussion . . . . . . . . . . . . . . . . . . . . 1420

Conclusion $\ldots \ldots \ldots \ldots \ldots \ldots \ldots \ldots \ldots \ldots \ldots \ldots \ldots \ldots \ldots$

APPENDIX A ......................... 1429

APPENDIX B. . . . . . . . . . . . . . . . . . . 1430

* Associate Professor, Indiana University Maurer School of Law-Bloomington; Director,. Law Firms Working Group (American Bar Foundation/Indiana Law). Some of the data used in this Article were made available pursuant to a special licensing agreement between the American Bar Foundation and American Lawyer Media (ALM). This article was prepared for Conference on Empirical Research on the Legal Profession: Insights from Theory and Practice, held at Georgetown University Law Center, on March 3, 2009.

** Professor of Management, Mays Business School, Texas A\&M University; Member, Law Firms Working Group. We would like to thank Marty Klaper, Robert Nelson, Carol Clayton, and our many research assistants for their indispensable contributions. 
During the last several decades, the legal profession's definition of a "large" corporate law firm has gradually shifted. The rise of mega-firms, with broad geographic platforms and highly sophisticated, specialized, and profitable practice groups, has been expedited by the steady erosion of the norm against lawyer movement between firms. This change in market structure and professional ethos is attributable to a confluence of factors, including the bureaucratization of corporate legal departments; the publication of law firm financials; the delineation of individual lawyers by prominence in various regional, national, or global markets; and the challenges of maintaining shared cultural values and long-term time horizons in the face of perpetual growth imperatives driven by the promotion to partnership tournament.

To date, commentators have described this process without necessarily articulating a logical endpoint. The purpose of this essay is to assemble the empirical facts of the "age of lawyer mobility" and, in turn, to offer some preliminary observations on: (a) the internal economic logic that propels the growth strategies of most large U.S. law firms; (b) how these strategies collectively pròduce a value proposition increasingly less attractive to clients and young lawyers; (c) structural problems within most large firms that inhibit their ability to effectively adapt to changing market conditions; and therefore (d) why many large law firms are vulnerable to small and mid-sized competitors who, by virtue of their size, have the flexibility to emphasize cost, collegiality, innovation, collaboration, and shared risks, both within the firm and with clients. Although a substantial number of large firms will continue to prosper, primarily by attracting lateral partners with the most lucrative and loyal clientele, most large firms (i.e., Am Law 200 or NLJ 250) will likely have to retool their business models in order to survive.

\section{INTRODUCTION}

Whenever lawyers, law professors, or law students discuss "large" law firms, the context is obvious to all-i.e., the corporate law firms that dominate the large metropolitan markets. These organizations, which are readily listed in The American Lawyer and the National Law Journal, all employ several hundred lawyers or more. Yet, when viewed in historical perspective, these same firms have undergone profound structural shifts. To illustrate our point, consider the following statistics, which are drawn from the nation's largest law firms based on the number of attorneys (NLJ 250) and span the career of the typical large law firm senior partner:

- In 1978, the average NLJ 250 firm had 45 partners and 102 attorneys. By 2008 , the average was 213 partners $(+473 \%)$ and 535 attorneys $(+525 \%)$.

- Baker \& McKenzie was the largest firm in 1978 (434 attorneys) followed by Vinson \& Elkins (272 attorneys). In 2008, firms of comparable size would be ranked \#106 and \#158 respectively. 
- In 1978, the average NLJ 250 firm had 2.5 offices, including its headquarter location. Sixty-seven firms had a single office. In 2008, the average NLJ 250 firm had 10.2 offices; only seven firms had a single office.

- Thirty years ago, NLJ 250 firms had a total of 84 offices and 567 lawyers in foreign locations. Today, the figures have increased to 562 offices and 14,198 lawyers abroad.

- Since 1993, when the NLJ started collecting data on nonequity partnerships, the average size of the nonequity tier has increased from 12 to 60 partners $(500 \%)$. Similarly; leverage (the ratio of total attorneys to equity partners) has grown from 2.70 to 3.51 (an increase of $30 \%$ ).

- Between 1980 and 2007, the average starting salary of an NLJ 250 associate in a large market increased from $\$ 28,340$ to $\$ 143,288(406 \%)$. During the same period, the average family household income increased from $\$ 24,118$ to $\$ 79,974(232 \%)^{1}$

The purpose of this brief empirical study is to examine how the market for legal talent operates in an environment in which the typical large law firm has become much larger and more geographically dispersed. From the perspective of organizational theory, norms of collegiality, loyalty, and shared firm history and culture are bound to be less effective "glue" among hundreds of partners in far-flung branch offices, versus a few dozen working down the hall from each other, which was the large firm norm when many current law partners joined the profession.

Arguably, many large firms have inadvertently reached a tipping point that is triggered by innate human limitations. The British anthropologist and evolutionary biologist Robin Dunbar has studied the group behavior and cohesion of a wide range of primates, including humans. According to Dunbar, there is a cognitive limit to the number of stable relationships any individual can maintain, which is a direct function of the size of the neocortex. ${ }^{2}$ Beyond this limit, peer pressure and group norms are no longer effective for maintaining group cohesiveness. For human beings, the so-called "Dunbar number" is $150 .^{3}$

1. See U.S. Census Bureau, Historical Income Tables-Households, http://www.census.gov/hhes/www/ income/histinc/h09AR.html (last visited April 14, 2009). For compelling evidence that the pay scale of large corporate law firms has undergone a dramatic structural shift over the last 15 years, see William D. Henderson, How the "Cravath System" Created the Bi-Modal Distribution, Empirical Legal'Studies Blog, July 18, 2008, http://www.elsblog.org/the_empirical_legal_studi/2008/07/how-the-cravath.html.

2. See Robin M. I. Dunbar, Co-Evolution of Neocortex Size, Group Size and Language in Humans, 16 Behav. \& BRAIN SCI. 681 (1993). The application of the Dunbar number to law firms was originally suggested by one of our students, John Infante (Indiana Law '08), who read about this research in Malcolm Gladwell's well known book, The Tipping Point.

3. Id. (basing 150 optimal group size for humans on data on group and neocortex size plus number examples from history and anthropology that support and corroborate this estimate). In 2007, 18 firms in the Am Law 100 had-fewer than 150 partners, and all tended to be geographically compact, fill distinctive niches, and reap very high profits. See Marc S. Galanter \& William D. Henderson, Tournament Without End, AM. LAW., Dec. 2008 (calculating the number of Am Law 100 firms with fewer than 150 partners). 
Heightened lateral mobility is one of the most conspicuous features of the modern legal marketplace, ${ }^{4}$ and it is both a cause and effect of reduced firm cohesiveness. ${ }^{5}$ This study draws upon a unique dataset of over 19,000 lateral partners and senior lawyers between 2000 and 2007 to provide a descriptive overview of significant market trends and speculate on a possible medium or long-term equilibrium. It proceeds in three parts. Part I briefly summarizes the dataset, including information on the Am Law 200 during the observation period. Part II analyzes lateral movement along four dimensions: (1) geographic market; (2) firms by size, profitability, and tier structure; (3) movement by practice area; and (4) lateral movement between law firms and employment in government and private corporations. Finally, Part III offers some preliminary thoughts on an emerging equilibrium.

Forecasting the future is a tricky business. Nonetheless, one of the virtues of empirical research is that such speculation-which is a necessity for prudent managers-is more informed and, we hope, more accurate than beliefs formed on the basis of intuition, anecdote, and personal experience. From our vantage point, it appears that a large number of law firms appear to be "betting the firm" on attracting sufficient quantities of "bet the company" lawsuits ${ }^{6}$ or other high-end practices, such as capital markets work. ${ }^{7}$ This growth strategy gains the support of powerful partners by seeking to recruit more lawyers similar to them. In many cases, it also entails a large geographic spread and heightens the battle for lateral

4. Leslie D. Corwin, Response to Loyalty in the Firm: A Statement of General Principles on the Duties of Partners Withdrawing from Law Firms, 55 WASH. \& LEE L. REV. 1055, 1056 (1998) (observing that we have entered the "age of attorney mobility").

5. See Robert Hillman, The Hidden Costs of Lawyer Mobility: Of Law Firms, Law Schools, and the Education of Lawyers, 91 Ky. L.J. 299, 300 (2002) ("This is the era of lawyer mobility and law firm destabilization."). Law school deans and eminent lawyers have also lamented the reduced loyalty and trust implicit in heightened lateral movement. See, e.g., ANTHONY T. KRONMAN, THE LOST LAWYER 277 (1993) (dean of Yale Law School); Sol M. Linowitz, The BETRAYed Profession: LaWYERING AT THE END Of THE TwENTIETH CENTURY 32-33 (1994) (former general counsel at Xerox Corporation and partner at Coudert Brothers).

6. Cf. Niraj Chokshi, Despite the Economy, 2007 was a Rich Year. 2008? Not So Much ..., RECORDER, Feb. 28, 2008, at 1 (quoting Chairman of Paul Hasting, "Our strategy over the past few years has been to focus on more highly valued, complex cases, and to be called on for bet-the-company cases"); Robert F. Ruyak, Keeping the Work Inhouse, LEGAL TIMES, Apr. 17, 2006, at 39 (managing partner of Howrey stating that 600-lawyer-firm increasingly "focus[es] on large 'bet-the-company' litigation"). Kyrsten Crawford, The Aristocrats, AM. LAW., Dec. 1997, at 70 (consultant Peter Zeughauser praising Munger, Tolles for "stak[ing] out a slice of the market they wanted ... the high-end, bet-your-company, non-price-sensitive work," which he likens to that of New York's Cravath, Swaine \& Moore).

7. Andrew Longstreth, Dubai Dreams, CORP. COUNSEL, Dec. 2006, at 92 (Skadden Arps lawyer describing firm's focus as one based on large, cross-border transactions); Attila Berry, Washington Kept Outside the Magic Circle, LEGAL Trmes, at 16 (noting that "the Magic Circle firms, as the top five British shops are known, focus largely on high-end capital markets and project finance work out of their London base"); Elizabeth Goldberg, The Departed, AM. LAW., May 2007 at 145 (reporting that Morrison \& Foerster's strategic plan includes "building such practices as global capital markets", Akin Gump has "decided to focus on attracting high-end work in six key practice areas", and Orrick has pursued "a ten-year drive toward high-margin work"); Anthony Lin, Ten Firms Hit \$2M Per Partner in Profits in 'O5, NAT'L L.J., at 10 (reporting that Cadwalader firm will likely continue "a heavy focus on its lucrative capital markets practice"). 
talent. $^{8}$ Wanting to attract and retain lawyers with the largest books for price-insensitive work, law firm managers increasingly focus on the profits per partner as reported to The American Lawyer rather than a long-term business strategy that delivers a highly valued and cost-effective service to clients. Specifically, the focus on high PPP has caused large firms to neglect the broad middle market, which pays overhead. Thus, many firms in the Am Law 200 are vulnerable to boutique or regional competitors with lower cost structures and organizational sizes that permit greater trust, cooperation, a longer time horizon, and ultimately greater value for clients. ${ }^{9}$

Unfortunately, within many large firms, the cost of any significant shift in business strategy would disproportionately fall on senior rainmakers, who are within five to fifteen years of retirement. Although a substantial number of large firms will continue to prosper, primarily by attracting lateral partners with the most lucrative and loyal clientele, most large firms (i.e., Am Law 200 or NLJ 250) will likely have to retool their business models in order to survive in the years to come. Yet, the likelihood of this transformation is significantly reduced by the sheer size and institutional inertia of most large law firm partnerships. In reality, it is extremely difficult to negotiate shared financial risk and a long-term time horizon when the preceding business model was forged decades earlier by a much smaller and localized group of lawyers. As a result, we see the next wave of innovation coming from small and middle-sized law firms, many of which may form in the wake of the current market shakeout.

\section{Summary of Data}

\section{A. LAWYER LATERAL MOVEMENT}

Beginning in 2000, The American Lawyer began tracking lateral partner moves in and out of the Am Law 200 and publishing an annual report. ${ }^{10}$ In 2004, Incisive Legal Intelligence (III), the magazine's publisher, began supplementing this database with information on partner movement between large U.S. and non-U.S. firms, particularly those foreign-based firms that are included in the Global 100, an ILI-published listing of the world's largest law firms based on revenues. The

8. See Part II.B, infra.

9. Cf. Ronald J. Gilson \& Robert H. Mnookin, Sharing Among the Human Capitalists: An Economic Inquiry into the Corporate Law Firm and How Partners Split Profits, 37 StAN. L. REv. 313, 321, 348-49, 352-53, 356 (1985) (citing reasons why a law firm with a "sharing ethos" and firm specific capital would ultimately provide better service and be more profitable than a firm that attempted to pay each partner at his or her marginal product); William D. Henderson, An Empirical Study of Single-Tier Versus Two-Tier Partnership in the AmLaw 200,84 N.C. L. Rev. 1691, 1742 (2006) (positing that firms that share the benefits and burdens of partnership will allocate work to the most cost-effective lawyers without squabbles over origination credits, thus "solidiflying] the firm's reputation for high quality services").

10. This report is traditionally published in the magazine's February edition and covers the prior year's lateral movement. 
information is collected by company journalists and staffers and augmented by other sources, such as legal industry publications, firm web sites and press releases. ${ }^{11}$ The objective of the publisher is to compile as complete a record as possible of lateral partners movement involving Am Law 200 firms during each calendar year. Because the composition of the Am Law 200 changes from year to year, the dataset obtained from $\mathrm{ILI}$ includes lateral movements involving many large firms slightly below the official Am Law 200 cutoff.

The ILI lateral partner database includes: (a) name of lawyer; (b) month and year of the move; (c) organization left; (d) city left; (e) organization joined; (f) city joined; (g) lawyer's practice area; and (h) source of the information. To capture movements within and across regional labor markets rather than municipal boundaries, the city data were recoded to the Census Bureau metropolitan level. ${ }^{12}$ Because practice group designations tend to vary from firm to firm, lawyers were coded based on a system of twelve discrete practice areas plus an "other" category for highly specialized niches. ${ }^{13}$ If a law firm that was left or joined was in the Am Law 200 during the year that the lateral movement occurred, the corresponding financial and demographic data, such as firm size and profits per partner, were added to the dataset.

For the 2000 to 2007 time period, the ILI lateral partner database contains 19,227 lateral movements. Of these lawyers, 10,984 (57.1\%) left and 15,244 (79.3\%) joined an Am Law 200 firm; thus, the net movement appears to be towards firms with larger revenues and presumably higher profits per partner (PPP). The average PPP of the firm left was $\$ 806,062$; the average PPP of the firm joined was $\$ 781,801$. When the sample is limited to movement within the Am Law $200(7,865)$, the average PPP of the firm joined is slightly higher than the average PPP of the firm left ( $\$ 877,255$ and $\$ 867,918$ respectively).

The lateral mobility dataset can be broken down by group movements and repeat movers. ${ }^{14}$ Of the 19,227 total movements, 10,898 senior lawyers $(56.7 \%)$ moved by themselves to a new practice setting; 4,704 (24.5\%) moved in groups of two to five senior lawyers; $1,986(10.3 \%)$ moved in groups of six to 20 senior lawyers; and 1,641 (8.5\%) moved in groups between 21 and 201. Merger or dissolution of an Am Law 200 firm accounted for 378 (2.0\%) and 708 (3.7\%) of the departures in the sample respectively. Based on a matching of names and

11. For the full description of the lateral partner movement methodology, see http://www.alacra.com/IncisiveLegal-Intelligence-Surveys-Lists-Rankings/Lateral_Partner_Moves-lateral_partner.

12. Under the system adopted by the Census Bureau in 2003, metropolitan areas are delineated by Core-Based Statistical Areas (CBSA). Where more than one CBSA are adjacent to one another and commuting patterns suggest interrelated labor markets, the CBSA are bundled into a single Consolidated Statistical Area (CSA). If the location fell within a CSA, it was coded accordingly; otherwise, the CBSA code was used. Foreign offices were coded using a scheme created by the Law Firms Working Group.

13. See infra Part II.C.

14. We define a group movement as lawyers who, during the same month and year, departed the same firm and joined the same firm and practice area. 
firms joined and left, approximately 1,550 lawyers (8.9\%) changed organizations twice during the observation period, and $169(0.9 \%)$ moved three or more times. For any sample year, one-time movers and serial movers tended to move to firms with similar profits per partner.

Table 1 summarizes lateral movement by year. Table 2 presents a descriptive overview of lateral movement by practice sector left or joined. Part II contains a more detailed analysis of lateral mobility trends by various other dimensions.

TABLE 1.

LATERAL MOVEMENT BY Year

\begin{tabular}{|c|c|c|c|}
\hline Year & Lateral Moves & Percent & Cumulative Percent \\
\hline 2000 & 1,998 & $10.4 \%$ & $10.4 \%$ \\
\hline 2001 & 2,478 & $12.9 \%$ & $23.3 \%$ \\
\hline 2002 & 2,183 & $11.4 \%$ & $34.6 \%$ \\
\hline 2003 & 2,193 & $11.4 \%$ & $46.0 \%$ \\
\hline 2004 & 2,733 & $14.2 \%$ & $60.3 \%$ \\
\hline 2005 & 2,752 & $14.3 \%$ & $74.6 \%$ \\
\hline 2006 & 2,063 & $10.7 \%$ & $85.3 \%$ \\
\hline 2007 & 2,827 & $14.7 \%$ & $100.0 \%$ \\
\hline Total & 19,227 & $100.0 \%$ & \\
\hline
\end{tabular}

TABLE 2.

Lateral Partner Movement by Practice Sector Left, Joined

\begin{tabular}{|l|r|r|r|r|}
\hline \multicolumn{1}{|c|}{ Practice Setting } & \multicolumn{2}{c|}{ Organization Left } & \multicolumn{2}{c|}{ Organization Joined } \\
\hline Am Law 200/Global 100 & 10,984 & $57.1 \%$ & 15,457 & $80.4 \%$ \\
\hline Non-Am Law 200 firm & 6,217 & $32.3 \%$ & 2,561 & $13.3 \%$ \\
\hline Corporation or Private Industry & 1,062 & $5.5 \%$ & 878 & $4.6 \%$ \\
\hline Federal Government & 702 & $3.7 \%$ & 164 & $0.9 \%$ \\
\hline State Government & 174 & $0.9 \%$ & 97 & $0.5 \%$ \\
\hline Non-Profit, Education, Other & 88 & $0.5 \%$ & 70 & $0.4 \%$ \\
\hline Total & 19,227 & $100.0 \%$ & 19,227 & $100.0 \%$ \\
\hline
\end{tabular}

B. THE AM LAW 200

The size and financial status of large law firms are important factors that presumably affect the market for lateral partners and other senior lawyers. As noted above, the majority of lateral movement in this dataset involved a lawyer 
moving to, from, or within the Am Law 200. An examination of the 2000 to 2007 time period reveals several significant trends affecting the average Am Law 200 law firm: ${ }^{15}$

- The number of lawyers increased from 399 to 534 (33.8\%)

- The number of equity partners increased from 120 to $138(15.2 \%)$

- The number of non-equity partners increased from 33 to $75(127 \%)$

- The percentage of single-tier (i.e., firms without non-equity partners) law firms declined from $27 \%$ (54 firms) to $16.5 \%$ (33 firms)

- Leverage (number of lawyers/equity partners) increased from 3.33 to 3.87 $(16.2 \%)^{16}$

- Revenues per lawyer have increased from $\$ 507,850$ to $\$ 736,100$ (44.9\%)

- Profits per equity partner have increased from $\$ 622,750$ to $\$ 1,065,325$ $(71.1 \%)$

Obviously, the typical firm is getting larger and much more profitable. However, an integral part of the business model appears to be fewer equity partners and higher leverage. In other words, proportionally fewer lawyers are sharing a much larger pie. Table 3 disaggregates firms by Am Law 200 rank

TABLE 3.

Changes in Am Law 200 Firm Characteristics, 2000 to 2007

\begin{tabular}{|c|c|c|c|c|c|c|}
\hline Quartile & $\begin{array}{c}\text { Am Law } \\
\text { Rank }\end{array}$ & Lawyers & $\begin{array}{c}\text { Equity } \\
\text { Partners }\end{array}$ & Leverage & RPL & PPP \\
\hline 1 & 1 to 50 & $44.9 \%$ & $21.2 \%$ & $19.5 \%$ & $47.3 \%$ & $78.6 \%$ \\
\hline 2 & 51 to 100 & $29.6 \%$ & $15.8 \%$ & $12.0 \%$ & $44.1 \%$ & $60.6 \%$ \\
\hline 3 & 101 to 150 & $26.8 \%$ & $7.3 \%$ & $18.2 \%$ & $45.4 \%$ & $85.8 \%$ \\
\hline 4 & 151 to 200 & $12.8 \%$ & $9.1 \%$ & $3.4 \%$ & $41.7 \%$ & $53.0 \%$ \\
\hline \multicolumn{2}{|c|}{ All } & $33.8 \%$ & $15.2 \%$ & $16.2 \%$ & $44.9 \%$ & $71.1 \%$ \\
\hline
\end{tabular}

(based on gross revenues) into quartiles. It appears that all quartiles followed the trend toward higher leverage and higher profitability. Yet, the top of the Am Law 100 (Quartile 1) and the top of the Am Law 101-200 (Quartile 3) have been the most aggressive in this strategy. Although the PPP has increased faster in Quartile 3 than Quartile 1 (85.6\% versus $71.1 \%$ ), the average PPP for a firm in the Am Law 50 nonetheless towers above the typical firm in the Am Law 101 to 150

15. These figures are firm averages rather than weighted averages. If RPL, PPP, and number of equity partners were weighted by the number of lawyers, the averages would be slightly higher because larger firms tend to have higher RPL and PPP and more equity partners.

16. For a detailed explanation for why this definition of leverage is the best for firm-to-firm comparisons, see Henderson, supra note 9, at 1722-24. 
range ( $\$ 1.7$ million versus $\$ 874,200){ }^{17}$

\section{ANALysis of Lateral Mobility TRENDS}

Part II analyzes the lateral movement dataset along four dimensions. Section A examines lawyer mobility within and across specific regional labor markets, highlighting metropolitan areas with the greatest absolute and proportional lateral movement. Section B focuses on variation in lawyer movement by firm size, structure, and relative profitability. Section $\mathrm{C}$ analyzes movement by practice area and finds evidence of a separating dynamic in which specific practice specialties are migrating to more (or less) profitable law firms. Finally, Section D provides some trend data on movement to and from government and private corporations, which suggest that stints in these practice settings tend to augment a lawyer's human capital.

\section{A. GEOGRAPHIC TRENDS}

Although large corporate law firms ostensibly compete on a national or international scale, the competition for lawyers plays out in a very localized way. ${ }^{18}$ Of the 13,926 lawyer movements between law firms in which the dataset contains both the city left and the city joined, $95.6 \%$ involved lawyers changing firms within the same metropolitan area. The "churn" of partners, ${ }^{19}$ however, varies by metropolitan area.

To establish a baseline to assess the volume of lawyer movement, we calculated the proportion of Am Law 200 firms in fiscal year 2006 that worked in one of the ten largest U.S. markets, in London, in another foreign office, or in a non-top-ten market in the U.S. ${ }^{20}$ We then calculated the volume of

17. The higher profitability of firms in the Am Law 101-150 appears to be driven by several firms following distinctive strategies (e.g., plaintiffs' contingency work) that do not involve substantial geographic spread or a broad offering of practice specialties.

18. See Marc S. Galanter \& William D. Henderson, The Elastic Tournament of Lawyers: A Second Transformation of the Big Law Firm, 60 STAN. L. REv. 1867, 1890 \& n.81 (discussing intra-market movements of lateral partners during the 2000 to 2005 time period and noting that movement was "stunningly local").

19. In recent years, The American Lawyer observed the large number of partners joining or leaving large law firms and periodically reported on the volume of "churn". See, e.g., The Lateral Report: Churn, Baby, Churn, AM. LAW., Mar. 2005, at 108 (reporting churn rates - the number of lateral partners departed divided by the total lateral partners joined over the previous four years-for the Top 25 most acquisitive firms). In addition, "The Churn Report", which is published online by The Am Law Daily, tracks the comings and goings of partners at major firms. See, e.g., Rachel Breitman, The Churn: Lateral Movements and Promotions in the AmLaw 200, AM. LAw. DAIIY, Dec. 20, 2008, available at http://amlawdaily.typepad.com/amlawdaily/2008/12/the-churnlateral-moves-and-promotions-in-the-am-law-200.html.

20. We selected 2006 as a baseline year because it was toward the end of the observation period, and hence reflected underlying geographic growth patterns, and also because the data, which is labor intensive to code, was available from a related large law firm research project. See William D. Henderson \& Arthur Alderson, The Changing Economic Geography of Large U.S. Law Firms, paper presented at the 3rd Annual Conference on Empirical Legal Studies (Ithaca, NY, Sept. 12, 2008), available at http://ssm.com/abstract =1134223. 
lateral movement by location of organizations left and location of organizations joined. To ascertain whether the volume of movement within a regional market was proportionately higher or lower than the overall flow of large firm lateral movement, we calculated the ratio of regional movement to that region's overall share of Am Law 200 lawyers. The results are summarized in Table 4.

TABLE 4.

Am Law 200 LaWyers (2006), Lateral Movement (2000-2007), BY LOCATION

\begin{tabular}{|l|r|r|r|r|r|r|c|}
\hline \multicolumn{1}{|c|}{ Metro } & \multicolumn{2}{|c|}{$\begin{array}{c}\text { \# and } \\
\text { Am Law 200 } \\
\text { (200) }\end{array}$} & \multicolumn{2}{c|}{$\begin{array}{c}\text { Percentage } \\
\text { of Lawyers } \\
\text { Left }\end{array}$} & \multicolumn{2}{c|}{$\begin{array}{c}\text { \# and } \\
\text { Percentage } \\
\text { of Lawyers } \\
\text { Joined }\end{array}$} & $\begin{array}{c}\text { Total/Region } \\
\text { Ratio }\end{array}$ \\
\hline New York City CSA & 22,721 & $20.7 \%$ & 3,039 & $18.1 \%$ & 3,120 & $18.3 \%$ & 0.883 \\
\hline Washington DC CSA & 14,606 & $13.3 \%$ & 2,667 & $15.9 \%$ & 2,723 & $16.0 \%$ & 1.199 \\
\hline Chicago CSA & 7,352 & $6.7 \%$ & 1,221 & $7.3 \%$ & 1,243 & $7.3 \%$ & 1.088 \\
\hline San Francisco CSA & 6,283 & $5.7 \%$ & 1,152 & $6.9 \%$ & 1,145 & $6.7 \%$ & 1.172 \\
\hline Los Angeles CSA & 6,838 & $6.2 \%$ & 995 & $5.9 \%$ & 1,019 & $6.0 \%$ & 0.959 \\
\hline Boston CSA & 3,948 & $3.6 \%$ & 710 & $4.2 \%$ & 714 & $4.2 \%$ & 1.163 \\
\hline London & 3,867 & $3.5 \%$ & 701 & $4.2 \%$ & 682 & $4.0 \%$ & 1.135 \\
\hline Philadelphia CSA & 3,071 & $2.8 \%$ & 520 & $3.1 \%$ & 506 & $3.0 \%$ & 1.060 \\
\hline Dallas CSA & 2,829 & $2.6 \%$ & 498 & $3.0 \%$ & 508 & $3.0 \%$ & 1.155 \\
\hline Houston CSA & 2,821 & $2.6 \%$ & 455 & $2.7 \%$ & 477 & $2.8 \%$ & 1.088 \\
\hline Atlanta CSA & 2,821 & $2.6 \%$ & 383 & $2.3 \%$ & 380 & $2.2 \%$ & 0.867 \\
\hline Other Foreign Offices & 9,645 & $8.8 \%$ & 1,175 & $7.0 \%$ & 1,213 & $7.1 \%$ & 0.809 \\
\hline Rest of U.S. & 22,847 & $20.8 \%$ & 3,279 & $19.5 \%$ & 3,314 & $19.4 \%$ & 0.933 \\
\hline \multicolumn{1}{|c|}{ All } & 109,649 & $100 \%$ & 16,795 & $100 \%$ & 17,044 & $100 \%$ & 1.000 \\
\hline
\end{tabular}

One of the most striking features of the breakdown of lateral movement by geography is that the pace of the movement is seemingly mild in the largest market (.883 in New York City, $20.7 \%$ of the Am Law. 200) and in the smaller U.S. markets $(.993,20.8 \%)$. In contrast, London and the other large U.S. metropolitan areas tend to have proportionately higher volumes of lateral movement. Collectively, these regional markets comprise approximately $49.6 \%$ of the Am Law 200 lawyers but account for $55.1 \%$ of the lawyers changing firms (ratio of 1.11). There are at least two possible explanations for the proportionately lower number of lawyer movement in metro New York City: (1) NYC is very 
high leverage and thus has fewer partners as a percentage of total attorneys; ${ }^{21}$ and (2) a larger percentage of firms in NYC are highly profitable and enjoy firm-specific capital (e.g., firm reputation), which undercut a partner's ability and incentive to "grab and leave" valuable firm clients. ${ }^{22}$

Clear patterns emerge when geographic movement of lawyers is broken down by the financial performance of the firm joined. Table 5 summarizes this information.

TABLE 5.

AVERAGe PPP aNd RPL OF Firm JoINEd, 2000 To 2007

\begin{tabular}{|l|c|c|c|}
\hline \multicolumn{1}{|c|}{ Location } & Average PPP & Average RPL & N \\
\hline London & $\$ 1,082,799$ & $\$ 695,072$ & 683 \\
\hline Other Foreign Cities & $\$ 1,063,929$ & $\$ 678,745$ & 1217 \\
\hline New York City CSA & $\$ 908,197$ & $\$ 640,684$ & 3122 \\
\hline San Francisco CSA & $\$ 880,103$ & $\$ 641,290$ & 1149 \\
\hline Los Angeles CSA & $\$ 870,163$ & $\$ 640,883$ & 1019 \\
\hline Washington, DC CSA & $\$ 817,088$ & $\$ 625,388$ & 2766 \\
\hline Chicago CSA & $\$ 682,279$ & $\$ 558,951$ & 1251 \\
\hline Rest of US & $\$ 648,233$ & $\$ 554,297$ & 5837 \\
\hline Total & $\$ 810,918$ & $\$ 610,817$ & 17,044 \\
\hline
\end{tabular}

Lateral lawyers in London, other foreign locations, and New York City tend to move to the most profitable firms. These figures are consistent with network analysis research on the NLJ 250, which has documented a growing nexus between New York City, London, and several European and Asian cities, presumably connected by capital markets transactional work. ${ }^{23}$ Movements in San Francisco, Los Angeles, and Washington DC are associated with joining a higher PPP firm. Although Chicago is the third largest market in terms of volume of lateral mobility, the movement tends to be to firms with below average PPP and RPL. This suggests that market dynamics in Chicago are likely to be closer to small and medium-sized legal markets than New York City or the large markets on the east or west coasts.

21. This trend was discovered in an earlier project, which relied upon branch office data of firms in the 2005 NALP Directory of Legal Employers and coded for firms in the 2005 Am Law 200. See William D. Henderson, Race and Gender Differences in U.S. Corporate Law Firms: A Preliminary Analysis, presentation to the Law Firms Working Group (Chicago, $\mathbb{L}$, Oct. 12, 2007) (on file with author) (documenting nonpartner to partner ratio of 2.09 for NYC versús 1.53 for San Francisco, 1.47 for Los Angeles, 1.34 for Washington DC, and 1.00 for Chicago).

22. See Henderson, Single-Tier versus Two-Tier, supra note 9, at 1727-29, 1742 (discussing interaction of geography, prestige, firm-specific capital, and law firm profitability).

23. See Henderson \& Alderson, supra note 20. 


\section{B. FIRM SIZE, STRUCTURE, AND PROFITABILITY}

In addition to geographic platform, lawyer lateral movement can be analyzed along the dimensions of firm size, structure, and profitability. One of the key metrics for lateral movement is the volume of partnership changes (additions or departures) within a given time period. ${ }^{24}$ To capture this change, we created several measures of lateral mobility relative to firm size. To account for year-to-year changes in the size of a partnership, we calculated the proportion of total lateral movement in and out of the firm that occurred in each year of the observation period. In turn, we used these values to create a weighted average of the total firm partners, which could be used to normalize (i.e., express as a percentage rather than a raw number) the total partners leaving or joining the firm. ${ }^{25}$ We refer to the volume of movement as the "partner velocity" in and out of the firm. The "net churn" is the velocity joining minus the velocity leaving. If this figure is positive, the firm is attracting more laterals than it is losing.

To capture other changes over time, we also calculated change variables for PPP, RPL, size of firm, size of partnership, and firm leverage by subtracting the value for fiscal year 2000 from the value for fiscal year 2007. As noted earlier, the overwhelming trend is toward two-tier partnership. ${ }^{26}$ Therefore, we analyzed tier structure based on a firm's status in 2007, the final year of the sample. The breakdown of statistics by tier structure is summarized in Table 6:

Table 6 reveals several noteworthy trends. For example, despite the fact that the average single tier firm was similar in size to the average two-tier firm through the observation period, lateral movement varied significantly by tier structure:

24. See, e.g., Goldberg, supra note 7, at 145 (reporting that Citigroup's law firm group routinely monitors "partner departures" but noting that a high number is no longer "immediately seen as a bad thing" because some departures may make the firm stronger in the long run); Nathan Koppel, Causing Lateral Damage: Rapid Partner Turnover Hits High Growth Firms, LEGAL TIMES, Mar. 7, 2005, at 20 (discussing several examples of firms that have aggressively hired lateral candidates but also experience rapid churn of their partnership with various departures).

25. For example, consider a firm in which 80 partners left between 2000 and 2007 , but the total number of partners was 200 in 2000 and 320 in 2007 . The weighted average method creates a weight by calculating the percentage of lawyers in each year (e.g., 8 in 2000,10\%; 16 in 2001, 20\%; 0 in 2002,0\%; 12 in 2003, $15 \%$; 0 in 2004, $0 \% ; 4$ in 2005, 5\%; 10 in 2006, 10\%; 32 in 2007,40\%). These weights are multiplied by the number of partners in each fiscal year (e.g., $10 \% \times 200,20 \% \times 220,0 \% \times 240, \ldots 40 \% \times 320$ ). The sum of these products is a weighted average of the partnership over eight years. This number is then used to normalize the total number of lawyers who left the firm (i.e., \# of lawyers left from 2000 to 2007/weighted average). The same procedure of weighting, averaging, and normalizing is used for lawyers who joined the firm.

26. See supra, Part I.B. 
TABLE 6.

Lateral Movement, Firm Size, Leverage, and PPP, by Tier Structure

\begin{tabular}{|l|r|r|r|r|}
\hline \multirow{2}{*}{\multicolumn{1}{|c|}{ Variable }} & \multicolumn{2}{c|}{ Single Tier } & \multicolumn{2}{c|}{ Two-Tier } \\
\cline { 2 - 5 } & Average & $\begin{array}{c}\text { Std. } \\
\text { Deviation }\end{array}$ & $\begin{array}{c}\text { Std. } \\
\text { Average } \\
\text { Deviation }\end{array}$ \\
\hline Number of Lawyers, 2000 & 446.6 & 500.4 & 412.0 & 224.2 \\
\hline Number of Lawyers, 2007 & 561.5 & 597.8 & 528.2 & 367.6 \\
\hline Change in Lawyers & 167.6 & 165.5 & 163.9 & 204.1 \\
\hline Lawyers Left** & 20.9 & 25.3 & 46.1 & 38.7 \\
\hline Lawyers Joined** & 40.5 & 64.3 & 79.6 & 78.6 \\
\hline Partner Velocity, Firm Left** & $13.6 \%$ & $8.9 \%$ & $22.4 \%$ & $14.9 \%$ \\
\hline Partner Velocity, Firm Joined** & $22.9 \%$ & $21.7 \%$ & $35.9 \%$ & $21.9 \%$ \\
\hline Net \% Change in Partnership & $9.9 \%$ & $20.4 \%$ & $13.6 \%$ & $18.1 \%$ \\
\hline PPP, 2000** & $\$ 966,724$ & $\$ 682,797$ & $\$ 568,451$ & $\$ 313,572$ \\
\hline PPP, 2007** & $\$ 1,607,879$ & $\$ 1,008,285$ & $\$ 958,114$ & $\$ 540,397$ \\
\hline Change in PPP** & $\$ 714,310$ & $\$ 432,451$ & $\$ 406,690$ & $\$ 355,269$ \\
\hline Leverage, 2000 & 3.19 & 0.95 & 3.39 & 0.99 \\
\hline Leverage, 2007* & 3.38 & 1.15 & 4.03 & 1.46 \\
\hline Change in Leverage** & $22.1 \%$ & $48.2 \%$ & $61.9 \%$ & $85.8 \%$ \\
\hline
\end{tabular}

* Mean of single tier is statistically different from two-tier at $\mathrm{p}<.05,{ }^{* *} \mathrm{p}<.01$

- Single-tier firms had fewer departures and arrivals (20.9 and 40.5) than two-tier firms (46.1 and 79.6); ${ }^{27}$

- Although there was no statistically significant difference between single-tier and two-tier firms in the net volume of lateral partners (partners gained minus partners lost), the overall partner velocity in and out of the firm was much lower in single-tier (13.9\% and $22.9 \%$ ) than two-tier firms (22.4\% and 35.9\%)-in other words, there tends to be greater turnover of partners in two-tier firms; ${ }^{28}$

- Single-tier firms were more profitable than two-tier firms in 2000 , and the average profit gap widened at statistically significant levels during the next eight years;

- Despite lagging profitability, two-tier firms increased their use of leverage at a much faster rate than single-tier firms. ${ }^{29}$

27. Using an independent sample t-test, the means departures and arrivals were statistically different for single-tier versus two-tier at $\mathrm{p}<.01$.

28. Using an independent sample t-test, the means departures and arrivals were statistically different for single-tier versus two-tier at $\mathrm{p}<.01$.

29. This trend is consistent with another study, which observed that in two-tier firms, an expansion in the non-equity tier appeared to operate as a functional substitute for associate lawyers. See John Gordanier, 
Attracting and retaining key lateral talent is often an important element of a law firm's strategy. Firms want higher profitability to attract better lateral hires; in turn, the lateral hires can increase firm profits, thus giving momentum to an upward virtuous cycle. ${ }^{30}$ To better explore the relationship between firm lateral movement and firm profits, we generated a scatterplot in which the net inflow/outflow of partners from . 2000 to 2007 is plotted against the natural log of PPP for fiscal year 2007. These results are displayed in Figure 1.

The most significant feature of Figure 1 is that there is no statistically significant linear correlation between firm profitability and higher net inflow of lateral recruitment. Rather, the best fitting model is a quadratic function in which the in-flow of laterals is associated with higher PPP among firms at the lower end of the profitability distribution (an upward sloping line); but among more profitable firms, higher profits are associated with fewer partners joining the firm laterally. ${ }^{31}$ Although there are many firms with a high net inflow of partners and PPP in excess of $\$ 1$ million (natural log of 13.81 or higher), all firms with profits per partner in excess of $\$ 2$ million (natural log of 14.51 or higher) have net inflows or outflows of partners between $-20 \%$ and $+20 \%$ over an eight year period. This observation suggests that highly profitable firms-most of them single-tier-are not dependent upon lateral mobility to generate high profits. Rather, these firms appear to possess other attributes, such as a highly specialized practice niche or a firm reputation, which binds clients to the firm. Indeed, large inflow and outflows of partners are likely to undercut the firm's competitive standing. ${ }^{32}$ To assess whether net inflow/outflow is associated with larger increases in PPP during the 2000 to 2007 time period, we plotted net inflow/ outflow against the natural log of the change in PPP. Once again, no linear

Interaction Between Law Firm Structure, Hiring, and Partner Promotion, in LAw FiRMS WorkING GrouP ANNUAL REPORT 6-8 (2009).

30. See, e.g., Goldberg, supra note 7, at 145 (reporting that Calwalader's strategy is to "attract important laterals" in its most profitable practice areas); Zusha Elison, Lateral Favorites, RECORDER, May 7, 2007, at 4 (reporting that "more and more law firms base their business and growth strategies around lateral hires"); Danilo DiPietro, Breaking Away: Am Law 100 Firms are very Profitable, but a Few Consistently Lead the Pack, AM. LAW., May 2006, at 67 (reporting that a key feature of the most profitable firms is the ability to "attract high-quality laterals"); Julie Triedman, Rainmaker Magnet, AM. LAw., Feb. 2006, at 79 (reporting on LeBoeuf Lamb's strategy to "attract big-ticket laterals"); Ward Bower, Law Firm Merger-What is the End Game?, N.Y. L.J., July 6, 2005, at 4 (reporting that the goals of a merger typical include not only the ability to attract "bigger and better clients, but to improve a firm's ability to recruit at both the associate and lateral partner levels); Jeff Blumenthal, D'More Leaves Major Hagen to Start Own Legal Search Firm, LEGAL INTELLIGENCER, June 8, 2005, at 1 (reporting on law firm recruiters role in "devising strategies to better attract laterals").

31. An earlier study documented a similar curvilinear relationship between firm profitability and growth in a law firm partnership size, with the highest profits tending to be present at firms with very low or very high rates of partnership growth. See Galanter \& Henderson, The Elastic Tournament, supra note 18, at 1885-87 fig. 6.

32. See Henderson, supra note 9, at 1697-98 (positing, based on empirical evidence, that "partners at highly profitable single-tier firms lack the incentive, and possibly the ability, to grab their full marginal product by leaving (or threatening to leave) the firm" and that high profits and client loyalties, in turn, create beneficial incentives "for efficient, high quality legal work that further solidifies a firm's reputation"). 
FIGURE 1. Net $\% \Delta$ in partnership (Y) and natural log of PPP (X)

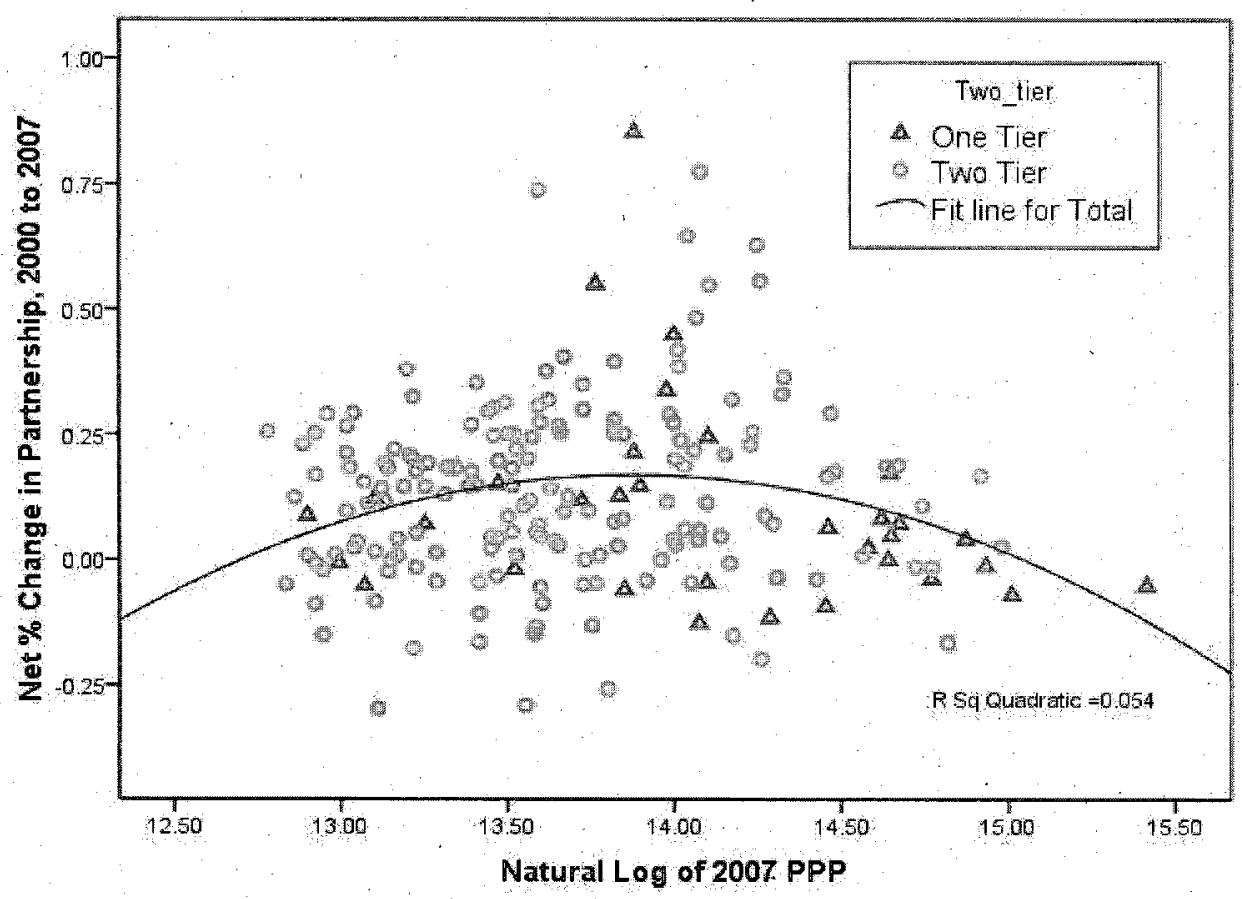

relationship was present and a mild concave quadratic function was observed. ${ }^{33}$

Another lateral strategy for increasing profitability may be the addition of important rainmaking partners and the deliberate shedding of partners who are in less lucrative practice areas or are perceived as underperforming. ${ }^{34}$ In other words, both additions and departures are viewed as net positives for the firm. To assess this theory, we generated another metric of lateral movement in which the inflows and outflows where added together (total \% change in partnership). Similar to the methodology for net inflow/outflow, this total "churn" variable was plotted against the natural log of 2007 PPP. The results are shown in Figure 2.

Similar to the net inflow/outflow metric, the total inflow/outflow of lateral partners has no linear relationship with PPP and an even more pronounced concave quadratic function in which a high churn approach is associated with mid-range profitability; conversely, high profitability is only compatible with a relative stable and immobile base of partners. Overall, no metric of lateral movement-partner velocity in, partner velocity out, net inflow/outflow, total

33. See Appendix, Figure A.

34. See, e.g., Goldberg, supra note 7 (reporting on perception of some firms and law firm strategists that a firm can be made strong by pruning underperforming partners and practice areas that do not fit the firm's long-term strategic plan). 
FIGURE 2. Total $\% \Delta$ in partnership (Y) and natural log of PPP (X)

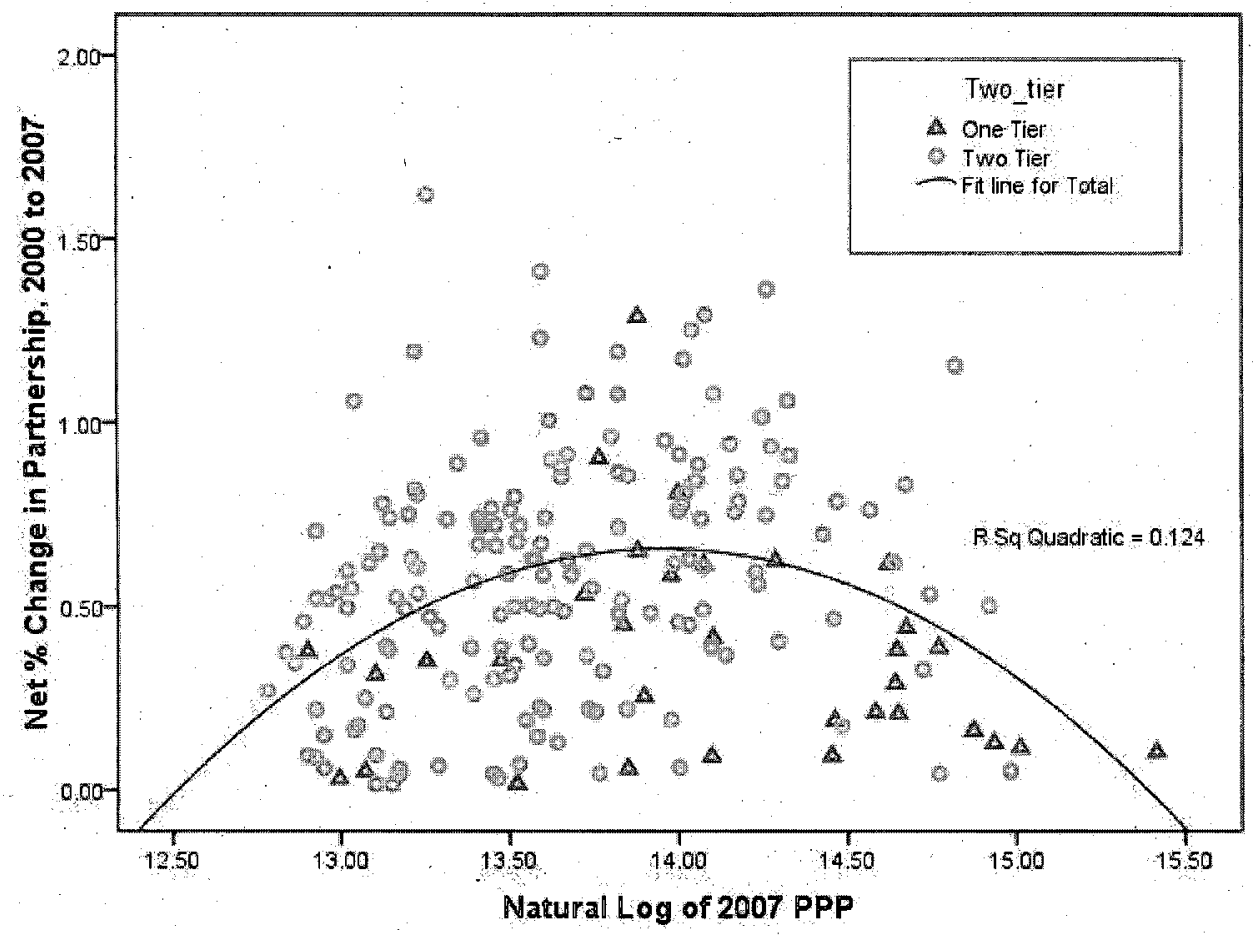

inflow/outflow-is consistent with an unambiguously positive relationship with higher firm profits or larger increase in profits over time. ${ }^{35}$ Indeed, firms with the highest PPP tend to have very low levels of turnover among partners.

A high volume of lateral movement, however, is associated with several other firm characteristics. For example, high total churn of partners (departure and arrivals combined) is positively correlated at statistically significant levels with gross revenues (.281), number of lawyers (.332), change in number of lawyers (.257), number of non-equity partners (.376), status as an Am Law 100 firm (.421), leverage (.246), and change in leverage 2000-2007 (.322). ${ }^{36}$

The picture that emerges from this analysis is not particularly heartening for those working in large law firms. High levels of lateral movement appear to be the dominant strategy for firms in the bottom and middle of the profitability

35. All $\mathrm{p}$-values for correlation coefficients were well above the .10 threshold. The lack of a linear relationship comports with the findings of a story by Hildebrandt International \& Citi Private Bank, which found similar levels of lateral and "home-grown" partners in high profitability versus low profitability law firms. See Hildebrandt International \& Citi Private Bank, Client Advisory (Jan. 2008), at 6-8 \& chart 5, available at http://www.hildebrandt.com/PublicDocs/2008_Client_Advisory_013008.pdf.

36. All $\mathrm{p}$-values significant at the $\mathrm{p}<.01$ level. 
spectrum. Yet, the data suggest that such an approach is nonexistent among the most profitable firms. Further, heavy reliance on lateral movement is associated with faster growth in the size of the firm. The combination of newcomers and greater firm size can dilute the sense of shared history, culture and values among partners, shorten their time horizons, and foment fractions within the firm. Firms with high volumes of lateral movement are also associated with larger increases in leverage. Some commentators have suggested the current generation of lawyers is less focused on the prize of equity partnership. ${ }^{37}$ Yet, those who have worked in the large firm sector for decades may be like the proverbial "boiling frog" that fails to react to a gradual change in water temperature ${ }^{38}$ - these lawyers do not adequately appreciate that the odds of obtaining an enduring equity partnership, and its perquisites, have changed dramatically over time. Unlike their senior lawyer counterparts, young associates immediately recognize that the water is hot-and not surprisingly, many jump out at their first opportunity. ${ }^{39}$

\section{LATERAL MOVEMENT BY PRACTICE AREA}

As noted earlier, the lateral lawyer dataset contains the name of the practice area that the incoming partner joined. After examining the data, the observations were grouped into twelve practice areas and an "other" category for a wide variety of highly specialized fields. To gauge the relative movement of practice

37. See, e.g., Dan DiPietro, Out of Lockstep, Legal. Times, Oct. 11, 2008, at 44 (observing that “[t]oday's associates are a different breed from those 25 years ago. Then, it was assumed that everyone was gunning for equity partnership and would work like crazy to get there.... Many [young associates now] demand a work-life balance that allows them to pursue other nonlegal interests and obligations. When they don't get the balance, they walk."). See also Galanter \& Henderson, The Elastic Tournament, supra note 18, at 1924-28 (discussing perception that Millennialist lawyers have a different set of values than prior generations and collecting sources).

38. The "boiling frog syndrome" is an analogy based upon 19th century experiments showing that frogs will readily jump out of a pot of boiling water but will boil to death if the water is slowly heated over a period of hours. See WALter WheEler SCRIPTURE, THE New Psychology 300 (1897) (discussing various similar experiments on frogs and citing Sedgwick, On the Variation of Reflex Excitability in the Frog Induced by Changes of Temperature, STUD. BIOL. LAB. JOHNS HOPKINS UNIVERSITY 385 (1882), as the source of the original story). See also Patrick Chisholm, Making a Bad Train Wreck Worse, ChristuAN SCI. MonITOR, Dec. 30, 2003, at 25 (applying boiling frog analogy to. government entitlement spending); Lou Dobb, Coming Up Empty, U.S. NEWS \& WORLD REP., Jan. 26, 2004 (applying boiling frog analogy to the U.S. economy and free trade); Bill Coffin, Boiling Frogs, RISK MGMT., Nov. 1, 2006, at 6 (describing "boiling frog syndrome" and opining that "everybody in every line of work is susceptible to it").

39. An earlier empirical study of Am Law 200 midlevel associates used multivariate regression analysis to analyze factors associated with a higher likelihood of an associate staying with the firm. The findings display a relatively intuitive and unambiguous set of tradeoffs. A higher likelihood of staying with the firms for two years or longer was associated (at statistically significant levels) with: (a) more interesting work; (b) higher "quality" work; (c) shorter work weeks; (d) a more family-friendly workplace; (e) a higher ratio of non-equity to equity partners, presumably because it increased the odds of "making partner"; and (f) greater communication regarding partnership prospects. After controlling for all of these factors, combined salary and bonus had no statistical relationship to midlevel associate's desire to remain with the firm. See William D. Henderson \& David Zaring, Young Associates in Trouble, 105 Mich. L. REv. 1081100-01 \& tbl.47 (2007) (book review). 
area, we coded each lateral movement as either "upstream" or "downstream". Upstream movements involve a lawyer moving from a firm outside the Am Law 200 to a firm in the Am Law 200, or going from a less profitable to a more profitable firm within the Am Law 200. Downstream movement had the opposite characteristics. Table 7 contains a breakdown of the lateral movement by practice area and by upstream or downstream movement.

TABLE 7.

Volume/Direction of Lateral Movement, By Practice Area, 2000-2007

\begin{tabular}{|l|r|r|r|c|c|}
\hline \multicolumn{1}{|c|}{ Practice Area } & N & $\begin{array}{c}\text { \% of } \\
\text { All }\end{array}$ & Upstream & Downstream & $\begin{array}{c}\% \\
\text { Upstream }\end{array}$ \\
\hline White Collar, Sec. Enfor. Litig.** & 152 & $1.1 \%$ & 114 & 38 & $75.0 \%$ \\
\hline M\&A, Cap markets, priv. equity** & 731 & $5.4 \%$ & 537 & 194 & $73.5 \%$ \\
\hline Intellectual Property** & 1,567 & $11.5 \%$ & 1,109 & 458 & $70.8 \%$ \\
\hline Corporate Securities* & 2,086 & $15.4 \%$ & 1,418 & 668 & $68.0 \%$ \\
\hline Litigation & 2,444 & $18.0 \%$ & 1,635 & 809 & $66.9 \%$ \\
\hline Antitrust & 187 & $1.4 \%$ & 124 & 63 & $66.3 \%$ \\
\hline Labor \& Employment & 932 & $6.9 \%$ & 614 & 318 & $65.9 \%$ \\
\hline Real Estate, Public/Proj. Finance & 1,009 & $7.4 \%$ & 663 & 346 & $65.7 \%$ \\
\hline Bankruptcy & 365 & $2.7 \%$ & 237 & 128 & $64.9 \%$ \\
\hline Business Law* & 1,526 & $11.2 \%$ & 964 & 562 & $63.2 \%$ \\
\hline Regulatory** & 1,107 & $8.2 \%$ & 675 & 432 & $61.0 \%$ \\
\hline Other** & 1,292 & $9.5 \%$ & 762 & 530 & $59.0 \%$ \\
\hline Trusts \& Estates** & 177 & $1.3 \%$ & 93 & 84 & $52.5 \%$ \\
\hline & 13,575 & $100 \%$ & 8,945 & 4,630 & $65.9 \%$ \\
\hline
\end{tabular}

* Statistically different from group mean at $\mathrm{p}<.05$, ** different at $\mathrm{p}<.01$.

One of the most striking features of the breakdown by practice area and direction of movement is that, over the last eight years, the mix of practice in the higher PPP Am Law 200 firms has shifted towards high-end/high stakes practice such as white collar crime, securities enforcement litigation, intellectual property, and corporate securities. Conversely, practices such as general business, regulatory compliance work, trust \& estates, and various "other" specialized practices are more likely to cluster at lower PPP firms or at smaller firms out of the Am Law $200 .^{40}$

40. These pattems are similar to an analysis based on the 2000 to 2005 time period. See Galanter \& Henderson, supra note 18 , at 1902-03 \& tbl. 4. 
Because a large number of observations in the lateral lawyer dataset include PPP data for the firm left and the firm joined, it is possible to calculate average PPP differentials by practice area, effectively revealing a market valuation of each practice area. These data are summarized in Table 8, which is ordered by PPP of firm joined.

TABeE 8.

MEAN PPP OF Firms LEFT, JOINED WITHIN AM LAW 200, 2000-2007

\begin{tabular}{|l|r|r|r|r|}
\hline \multicolumn{1}{|c|}{ Practice Area } & $\begin{array}{c}\text { PPP of } \\
\text { Firm } \\
\text { Left }\end{array}$ & $\begin{array}{c}\text { PPP of } \\
\text { Firm } \\
\text { Joined }\end{array}$ & $\begin{array}{c}\text { Difference } \\
\text { in PPP }\end{array}$ & \multicolumn{1}{c|}{ N } \\
\hline White Collar and Securities Enfor. Litig** & $\$ 876,233$ & $\$ 1,046,507$ & $\$ 170,274$ & 73 \\
\hline Antitrust & $\$ 971,667$ & $\$ 1,037,072$ & $\$ 65,405$ & 111 \\
\hline M\&A, Capital Markets, Priv. Equity** & $\$ 914,309$ & $\$ 1,005,186$ & $\$ 90,878$ & 376 \\
\hline Intellectual Property** & $\$ 819,365$ & $\$ 922,622$ & $\$ 103,257$ & 717 \\
\hline Bankruptcy & $\$ 913,511$ & $\$ 922,394$ & $\$ 8,883$ & 188 \\
\hline Business Law** & $\$ 951,625$ & $\$ 897,510$ & $-\$ 54,116$ & 769 \\
\hline Corporate Securities & $\$ 890,961$ & $\$ 875,445$ & $-\$ 15,516$ & 1046 \\
\hline Real Estate, Public \& Project Finance & $\$ 865,995$ & $\$ 842,385$ & $-\$ 23,610$ & 392 \\
\hline Other & $\$ 869,223$ & $\$ 833,867$ & $-\$ 35,356$ & 534 \\
\hline Litigation & $\$ 837,463$ & $\$ 819,540$ & $-\$ 17,923$ & 869 \\
\hline Regulatory & $\$ 773,283$ & $\$ 759,434$ & $-\$ 13,849$ & 530 \\
\hline Labor \& Employment & $\$ 712,372$ & $\$ 719,193$ & $\$ 6,822$ & 409 \\
\hline Trusts \& Estates** & $\$ 884,074$ & $\$ 688,426$ & $-\$ 195,648$ & 54 \\
\hline Total & $\$ 860,069$ & $\$ 862,194$ & $\$ 2,125$ & 6068 \\
\hline
\end{tabular}

** Difference in Mean between PPP firm left and PPP firm joined is significant at $\mathrm{p}<.01$.

An examination of the mean PPP of the firms joined and the differential from their prior firm suggest at least three significant patterns. First, there is a clear hierarchy of practice areas. Practitioners in business practices or high stakes litigation affecting company executives tend to join firms with PPP's of $\$ 875,000$ or higher. ${ }^{41}$ Second, within the business area, some specialized practices appear to be moving upstream (white collar crime, securities enforcement litigation, M\&A, capital markets, private equity) while a general business practice is moving downstream. Third, practices such as trust \& estates, labor \& employment, and regulatory (which includes environmental compliance, FDA, energy,

41. Note that these figures reflect averages over eight years. 
healthcare, and immigration) are disproportionately at lower PPP firms. ${ }^{42}$ These practice areas may be the so-called "commodity" areas that so many firms are trying to reduce or eliminate. ${ }^{43}$

To further explore the relative market value of particular practice areas, we specified a linear regression in which the dependent variable was the natural log of the PPP of the firm joined. ${ }^{44}$ The independent variables can be grouped as follows:

- Fiscal Year. Because PPP changed significantly during this time period, a dummy variable (value of 1 or 0 ) was used for each year, using 2000 as a reference group. ${ }^{45}$

- Regional or Foreign Market. Separate dummy variables were used for lawyers who joined a firm in one of the Top 5 U.S. markets, London, or another foreign office. The reference group, therefore, is lawyers who joined firms in non-Top 5 U.S. markets.

- Practice setting left. Dummy variables for lawyers who left the following practice settings: Am Law 101-200, Am Law 51 to 100; Am Law 50, DOJ or U.S. Attorneys office, other federal employment, state government, or private industry. The reference group, therefore, is lawyers who joined an Am Law 200 firm from a non-Am Law 200 firm or other work setting.

- Firm Joined. Continuous variables for size of firm joined (in units of 100 lawyers) and leverage (lawyers per equity partner).

- Practice Area. Dummy variables for each practice areas. We omitted General Business and Litigation to serve as a reference group.

- Serial movers. To test whether lawyers moving for the second or third time tended to join higher PPP firms, we used a dummy variable, giving a value of 1 to lateral movements that were the second, third, or fourth moves.

The full regression results are contained in Appendix B. Based on the regression model, Table 9 contains a summary of the predicted marginal effects for each of the independent variables.

An inspection of p-values in Table 9 reveals that most variables are associated, at statistically significant levels, with higher or lower PPP of firm joined. The log

42. A similar analysis based on 2000 to 2005 appears in Galanter \& Henderson, The Elastic Tournament, supra note 18 , at $1900-01 \&$ tbl. 2.

43. See, e.g., Managing Partner Q\&A: Bradley Miller, LAw. PraC. MGMT., Dec. 2008, at 48 (quoting Ball Janik managing partner, Bradley Miller, "The big challenges [facing law firms] include ... maintaining a high-quality practice so as to avoid the challenges created by increased 'commodization' of certain aspects of many practices areas").

44. A natural $\log$ transformation is commonly used to model income data because a small number of observations often reflect very high incomes. The transformation typically produces a better fitting linear model and reduces the problem of nonrandom distribution of errors (i.e., heteroskedacity).

45. Fiscal year 2000 is the reference group because it is the one year in the sample which is not included using a dummy variable. As a result, the coefficients for each year reflect a change in PPP joined relative to fiscal year 2000 . 
TABLE 9.

MARginal EFFect of IndePendent Variables on PPP of Firm JoINED

\begin{tabular}{|c|c|c|c|c|c|}
\hline \multicolumn{2}{|r|}{ Variable } & \multirow{2}{*}{ Sig. } & \multicolumn{3}{|c|}{ \$ value at baseline.PPP of: } \\
\hline & & & $\$ 600,000$ & $\$ 860,000$ & $\$ 1,200,000$ \\
\hline \multirow[t]{2}{*}{ Year } & Year 2001 & NS & $\$ 2,559$ & $\$ 3,670$ & $\$ 5,116$ \\
\hline & Year 2002 & 0.005 & $\$ 47,991$ & $\$ 68,790$ & $\$ 95,980$ \\
\hline & Year 2003 & 0.000 & $\$ 89,786$ & $\$ 128,695$ & $\$ 179,569$ \\
\hline \multirow[t]{4}{*}{. } & Year 2004 & 0.000 & $\$ 200,493$ & $\$ 287,376$ & $\$ 400,983$ \\
\hline & Year 2005 & 0.000 & $\$ 207,961$ & $\$ 298,080$ & $\$ 415,918$ \\
\hline & Year 2006 & 0.000 & $\$ 287,468$ & $\$ 412,041$ & $\$ 574,933$ \\
\hline & Year 2007 & 0.000 & $\$ 317,285$ & $\$ 454,778$ & $\$ 634,566$ \\
\hline \multirow[t]{7}{*}{ Regional Market } & Joined DC Office & 0.000 & $\$ 90,553$ & $\$ 129,795$ & $\$ 181,103$ \\
\hline & Joined NYC Office & 0.000 & $\$ 107,760$ & $\$ 154,458$ & $\cdot \$ 215,516$ \\
\hline & Joined Chicago Office & 0.043 & $\$ 13,683$ & $\$ 19,615$. & $\$ 27,364$ \\
\hline & Joined San Francisco Office & 0.000 & $\$ 99,178$ & $\$ 142,158$ & $\$ 198,354$ \\
\hline & Joined LA Office & 0.000 & $\$ 89,025$ & $\$ 127,605$ & $\$ 178,047$ \\
\hline & Joined London Office & NS & $\$ 5,804$ & $\$ 8,320$ & $\$ 11,605$ \\
\hline & Joined other Foreign Office & 0.000 & $\$ 185,065$ & $\$ 265,263$ & $\$ 370,127$ \\
\hline \multirow[t]{7}{*}{ Setting Left } & Federal Prosecutor or DOJ & 0.000 & $\$ 70,101$ & $\$ 100,481$ & $\$ 140,200$ \\
\hline & Other Federal Employment & 0.000 & $\$ 90,836$ & $\$ 130,200$ & $\$ 181,668$ \\
\hline & State Govt Employment & NS & $\$ 26,362$ & $\$ 37,788$ & $\$ 52,721$ \\
\hline & Private Industry & NS & $\$ 1,729$ & $\$ 2,481$ & $\$ 3,456$ \\
\hline & Am Law 101-200 & NS & $\$ 15,345$ & $\$ 21,997$ & $\$ 30,688$ \\
\hline & Am Law $51-100$ & NS & $-\$ 25,874$ & $-\$ 37,084$ & $-\$ 51,751$ \\
\hline & Am Law 50 & 0.000 & $\$ 106,194$ & $\$ 152,214$ & $\$ 212,385$ \\
\hline \multirow[t]{2}{*}{ Firm Joined } & Number of Lawyers (100s) & 0.000 & $\$ 4,107$ & $\$ 5,889$ & $\$ 8,212$ \\
\hline & Leverage & 0.000 & $\$ 99,639$ & $\$ 142,819$ & $\$ 199,276$ \\
\hline \multirow[t]{11}{*}{ Practice Area } & Regulatory & 0.000 & $-\$ 26,349$ & $-\$ 37,766$ & $-\$ 52,701$ \\
\hline & Antitrust & 0.000 & $\$ 82,430$ & $\$ 118,152$ & $\$ 164,857$ \\
\hline & M\&A, Cap. Mkt, Priv. Equity & 0.000 & $\$ 77,145$ & $\$ 110,577$ & $\$ 154,288$ \\
\hline & Intellectual Property & 0.000 & $\$ 50,060$ & $\$ 71,755$ & $\$ 100,117$ \\
\hline & Labor \& Employment & 0.000 . & $-\$ 66,391$ & $-\$ 95,159$ & $-\$ 132,784$ \\
\hline & Real Estate, Public/Project Fin. & 0.003 & $-\$ 20,346$ & $-\$ 29,160$ & $-\$ 40,694$ \\
\hline & White Collar \& Sec. Enfor. & 0.000 & $\$ 97,681$ & $\$ 140,012$ & $\$ 195,359$ \\
\hline & Trusts \& Estates & 0.004 & $-\$ 49,140$ & $-\$ 70,432$ & $-\$ 98,282$ \\
\hline & Bankruptcy & 0.001 & $\$ 38,659$ & $\$ 55,414$ & $\$ 77,316$ \\
\hline & Corporate Securities & 0.000 & $\$ 32,469$ & $\$ 46,540$ & $\$ 64,934$ \\
\hline & Other Practice Areas & NS & $\$ 805$ & $\$ 1,155$ & $\$ 1,607$ \\
\hline Serial & Second or Third move & NS & $\$ 463$ & $\$ 666$ & $\$ 924$ \\
\hline
\end{tabular}


transformation of PPP left, however, makes it difficult to quickly grasp the practical implications of the regression results. Therefore, to ease interpretation of the results, Table 9 calculates the predicted marginal effect of the independent variable on PPP joined at three hypothetical PPP values for law firm joined: $\$ 600,000, \$ 860,000$ (roughly the mean of the sample), and $\$ 1.2$ million. For example, consider two lateral partners who are identical on all dimensions, but the first joins a firm in a non-Top 5 market, and the second joins the DC office of a different firm. The model predicts that the first will make $\$ 600,000, \$ 860,000$, or $\$ 1.2$ million (depending on the values of the other independent variables), while the second will make $\$ 690,553(\$ 600,000+$ $\$ 90,553)$, $\$ 989,795(\$ 860,000+\$ 129,795)$, or $\$ 1,381,103$ ( $\$ 1.2$ million $+\$ 181,103)$. Therefore, compared to a non-Top 5 location, movement within the Washington, DC market tends to be to higher profitability firms.

Drawing upon this analysis, the following key findings emerge:

- Geography. There appears to be a geographic hierarchy based on PPP joined, with the highest premium associated with a non-London foreign office, followed by New York, San Francisco, Washington DC, Los Angeles, and Chicago.

- Practice Setting. Lawyers leaving an Am Law 50 firm tend to migrate to higher PPP firms, as do lawyers leaving the U.S. Attorneys Office, the DOJ, or other federal employment. In contrast, there is no statistically significant relationship between PPP of firm joined and employment in state government, private industry, or an Am Law 51 to 200 firm.

- Structure of firm joined. The model controlled for size and leverage of firm joined. Both attributes are associated with higher PPP.

- Practice Area. The model sets forth a relative hierarchy of practice areas, with White Collar and Securities Enforcement associated with the highest PPP, followed by Antitrust; M\&A, Capital Markets, and Private Equity; and Intellectual Property. Practice areas associated with lower PPP include (from smaller to larger decline in PPP) Real Estate-Public/Project Finance, Regulatory, Trust \& Estates, Labor \& Employment.

- Serial mover. Controlling for the above factors, second or third moves bear no statistically significant relationship to PPP of firm joined.

In summary, this section examined lateral mobility and practice areas using three methods of analysis: (1) examining the proportion of movement to larger or smaller firms; (2) calculating the mean difference between firms left and firms joined; and (3) multivariate regression. All these methods suggest that the relative mix of practice within large law firms is in a state of flux, with more lucrative practice areas generally moving to larger, more profitable, and higher leveraged firms. ${ }^{46}$ Conversely, movement of partners in so-called commodity practice areas

46. See Galanter \& Henderson, The Elastic Toumament, supra note 18, at 1904-06 (examining similar data for the 2000 to 2005 time period and positing the likelihood of a "separating dynamic" among large U.S. law firms). 
is generally occurring at lower PPP firms within the Am Law 200 or smaller firms. The implication is that large law firms are trending toward greater specialization rather than diversification. ${ }^{47}$

From the perspective of law firm managers and powerful partners, this strategy makes theoretical sense. Allocating overhead and dividing profits is presumably easier when the vast number of partners specialize in high margin work. And the high PPP can attract better talent, thus creating virtuous cycles of upward profitability. Most importantly, the partners with the most lucrative and portable books of business are not asked to change or sacrifice for the long-term positioning of the firm. The risk of this approach, however, is the likelihood that a large number of large firms converge on the same "high-end premium work" while most corporate general counsels focus on ways to control or stretch their legal budgets. ${ }^{48}$ Such dynamics may be pumping up a speculative bubble in the market for lateral partners akin to recent events in the real estate or stock markets. This difficult coordination problem is addressed again in Part III.

\section{LAW FIRM MOBILITY AND GOVERNMENT AND PRIVATE INDUSTRY EMPLOYMENT}

The lateral mobility data also permit an examination of movement between law firms and jobs in government and private industry. As noted previously, of the 19,227 lateral movements in the sample, $10.4 \%$ of the senior lawyers were migrating from non-law firm employment to a law firm; and $6.3 \%$ were leaving a law firm for a job in government, private industry, or another setting, such as a non-profit organization. ${ }^{49}$ Fortunately, the dataset permits some analysis of inter-sector movement by law firm financials, geographic markets, and practice areas.

The data support the observation that non-law firm employment in government, private industry, or another setting (e.g., education or non-profit organization) enhances the value of lawyers' human capital, at least as measured by the profits per partner (PPP) of the law firm left or joined. As summarized in Table 10 , the average PPP of the law firms joined is higher, at statistically significant levels, than the average PPP of law firms left. ${ }^{50}$

47. This is contrary to the theory that diversification of practice areas is the primary driver of large law firm growth. Cf. Gilson \& Mnookin, supra note 9 (theorizing that the benefit of a large corporate law firm is the accumulation of practice areas that are countercyclical, thus reducing risk for partners).

48. At a recent law firm presentation in London, a prominent general counsel suggested that no more than 5 percent of legal budget in any given year is truly price-insensitive. We have talked with several general counsel who agree that whatever the number is, it is less than $10 \%$ of total budget.

49. See supra, Table 2.

50. Although this sample is likely incomplete and biased, the bias is probably in the direction of understating the putative human capital human enhancement. For example, we might expect fewer firms to report departures; but among those that do, we would expect them to be the largest and most profitable firms. Conversely, all firms have a strong incentive to report the hiring of lateral partners who formerly served in prestigious positions. 
TABLE 10.

Movement Between Law Firms \& Private Industry, Government, OTHER

\begin{tabular}{|l|c|c|c|c|}
\hline \multirow{2}{*}{\multicolumn{1}{c|}{ Movement }} & \multicolumn{2}{|c|}{ Leaving Am Law 200 Firm } & \multicolumn{2}{c|}{ Joining Am Law 200 Firm } \\
\cline { 2 - 5 } & $\mathbf{N}$ & Mean & $\mathbf{N}$ & Mean \\
\hline Private Industry** & 856 & $\$ 698,551$ & 987 & $\$ 777,421$ \\
\hline Government** & 257 & $\$ 717,871$ & 818 & $\$ 841,009$ \\
\hline Other* & 25 & $\$ 684,000$ & 51 & $\$ 922,941$ \\
\hline
\end{tabular}

* Means of Leaving and Joining statistically different at $\mathrm{p}>.10, * * \mathrm{p}>.01$.

These figures may be partially explained by differences in opportunities that vary by regional labor markets. For example, when lateral movement within the U.S. is separated into Top 5 markets (New York City, Washington DC, Chicago, Los Angeles, and San Francisco) and all other domestic locations, 53.7\% $(9,312)$ of the organizations joined were located in Top 5 markets and $46.3 \%(8,026)$ in smaller metropolitan areas. Yet, when the movement from Am Law 200 to private industry (typically in-house positions) is analyzed, the majority of the positions are located in non-Top 5 markets $(63.2 \%){ }^{51}$. Conversely, movement from the government to Am Law 200 firms is much more likely to move in the opposite direction, with $69.3 \%$ of the movement (558) involving an Am Law 200 firm in a Top 5 market. ${ }^{52}$ These divergent patterns for movement between law firms and private industry and government are likely affected by (1) the changing economic geography of law firms and their clients, and (2) different opportunity costs for law firm partners and government lawyers who are working in major legal markets.

Regarding economic geography, earlier research has documented that since the mid-1980s, large corporate headquarters are migrating out of the Midwest and Northeast/Mid-Atlantic corridors toward locations in the Southwest, Southeast, and West Coast/Rocky Mountain regions. ${ }^{53}$ Yet, for reasons related to globalization and the growth of federal regulatory practice, the number of Am Law 200 lawyers remains heavily concentrated in several metropolitan areas, such as

Although larger firms may be more likely to issue a press release (and hence end up in the database), this propensity would not explain why the average PPP of firms departed would be significantly lower than firms joined.

51. Two-sided tests of proportions using z-test, significant at $\mathrm{p}<.05$.

52. Two-sided tests of proportions using z-test, significant at $\mathrm{p}<.05$.

53. See Henderson \& Alderson, supra note 20, at 12-13 \& tbl 5 (documenting that between 1984 and 2004 that the Midwest/Great Plains regions, which includes Chicago, and the Northeast/Mid-Atlantic region, which includes New York City, Washington DC, Philadelphia, and Boston, lost 37 and 33 Fortune 500 Headquarters respectively with gains distributed location to the south and west). 
Chicago and New York City, that are losing corporate headquarters. Further, although metropolitan Los Angeles, San Francisco, and Washington DC (which includes Northern Virginia) have gained a modest number of Fortune 500 headquarters, the number of Am Law 50 lawyers has grown at a much faster pace. ${ }^{54}$ Therefore, even though major corporations may retain lawyers in "global cities" to handle significant cross-border and regulatory matters, lawyers in smaller markets are more likely to live and work in the same metropolitan area as corporate executives. This spatial distribution may create greater opportunities to obtain a senior in-house or general counsel position. Regarding opportunity costs, law firm partnership tends to be the most lucrative for Am Law 200 lawyers working in major legal markets. ${ }^{55}$ Thus, the financial perks of a corporate inhouse position (e.g., stock options) are likely to be less appealing for this group. ${ }^{56}$

An inspection of the data suggests that the reverse effect applies to government employment. As shown in Table 11, government attorneys working in the largest (and most expensive) metropolitan areas appear to have a very high opportunity cost. When lawyers who work for the Department of Justice, another federal agency, the U.S. Congress, or a state government leave to join a large corporate law firm, the PPP of the law firms joined is, on average, $\$ 250,000$ to $\$ 350,000$ higher in a Top 5 market.

TABLE 11.

Mean PPP of Am LaW 200 Firms Joined, 2000 to 2007, By Gov'T EMPLOYMENT AND Metro AREA

\begin{tabular}{|l|r|c|c|c|}
\hline \multirow{2}{*}{\multicolumn{1}{c|}{ Practice Setting Left }} & \multicolumn{2}{|c|}{ Top 5 Market } & \multicolumn{2}{c|}{ Smaller U.S. Metro areas } \\
\cline { 2 - 5 } & N & PPP firm joined & N & PPP firm joined \\
\hline DOJ or Office of US Attorneys** & 170 & $\$ 964,500$ & 72 & $\$ 657,500$ \\
\hline Other Federal Agency** & 247 & $\$ 940,951$ & 73 & $\$ 638,151$ \\
\hline U.S. Congress (member or staff)** & 57 & $\$ 774,474$ & 15 & $\$ 513,000$ \\
\hline State Government** & 68 & $\$ 949,044$ & 77 & $\$ 619,480$ \\
\hline
\end{tabular}

** Means of Top 5 and Non-Top 5 statistically different at $\mathrm{p}<.01$.

Further, it appears that within large markets, government attorneys command a price vis-à-vis other lateral partners who join through other practice settings such as law firms.

54. See id. at 13-15 \& Map. 2 (presenting figures on Am Law 50 lawyer growth between 1984 and 2004, with disproportionately large gains in Top 5 markets).

55. See supra, Table 5. See also Henderson \& Alderson, supra note 20, at 11 tbl. 4 (listing a weighted average of RPL and PPP based on Am Law 200 firms located in specific domestic and foreign markets).

56. In fact, among the 784 lawyers who left private industry for an Am Law 200 job, the average PPP of firm joined was $\$ 881,532$ in Top 5 markets versus $\$ 593,757$ in smaller metropolitan areas. This difference was statistically significant at $\mathrm{p}<.01$. 
- DOJ or Office of U.S. Attorneys. In Top 5 markets, these lawyers joined firms with an average PPP of $\$ 964,500$, versus $\$ 841,446$ for other senior lateral lawyers. ${ }^{57}$ In non-Top 5 markets, the figures were $\$ 657,500$, versus $\$ 634,105$ for other laterals.

- Other Federal Executive and Legislative Branch Lawyers. In Top 5 markets, these lawyers joined firms with average PPP of $\$ 940,951$, versus $\$ 840,964$ for other laterals. ${ }^{58}$ In non-Top 5 markets, the figures were $\$ 638,151$, versus $\$ 634,345$ for other laterals.

- State government Lawyers. In Top 5 markets, these lawyers joined firms with an average PPP of $\$ 949,044$, versus $\$ 843,195$ for other laterals. ${ }^{59}$ In non-Top 5 , the figures were $\$ 619,481$, versus $\$ 634,591$ for other laterals.

The price premium for governmental experience is corroborated by results from the multivariate regression results reported in Section $C$ and displayed in Appendix B. A lateral lawyer moving from the federal executive or legislative branches tends to receive a price premium of approximately $\$ 100,000$ to $\$ 130,000$ at a medium-profitability Am Law 200 firm, even after controlling for fiscal year, practice area, geography, and attributes of the firm joined. ${ }^{60}$ In contrast, the regression results show no price premium (or discount) for lateral lawyers who joined the firm from state government.

\section{DISCUSSION}

Drawing upon the above review of lateral mobility and law firm financial data for the 2000 to 2007, Part III puts forward three observations on the marketplace for corporate legal services: (1) a large proportion of large firms have converged on the same business model - a large geographic platform in major national and global markets and a greater emphasis on premium, price-insensitive work; ${ }^{61}$ (2) due to the sheer size and geographic dispersion of many law firm partnerships,

57. Means statistically different at $p<.001$.

58. Means statistically different at $\mathrm{p}<.001$.

59. Means statistically different at $\mathrm{p}<.05$.

60. See Table 9, supra.

61. There are a handful of firms in the U.S. and U.K. (e.g., Cravath Swaine \& Moore, Wachtell Lipton, and Slaughter \& May) that successfully resist geographic spread primarily because their core practice areas are so strong and lucrative. Yet, this strategy is available only to those firms with a marquee reputation that draw both clients and talented lawyers to the firm. See Galanter \& Henderson, The Elastic Toumament, supra note 18, at 1884-88 \& fig. 6 (categorizing firms need to grow based on the interaction between reputation and geographic spread and noting that "lower reputation (i.e., lower-prestige) firms will often track the geographic growth of clients of their client base in an effort to dissuade clients from hiring rival firms" and that "the need for geographic coverage . . . is a non-toumament factor that will affect the size of a law firm partnership"). See also Tony Angel, Sustaining Partnership in the Twenty-First Century: The Global Law Firm Experience, in MANAGING THE MODERn LAW FIRM 196, 200 (Laura Empson, ed., 2007) (recounting historical competition among elite law firms and noting that large and lucrative domestic market in U.S. has "lessen the[ ] immediate need-and appetite—-to expand abroad" among "ultra-profitable elite New York firms-the natural competitors to the magic circle in the finance area"). 
there is an internal economic logic that significantly undermines firms' ability to aggressively pursue alternative business models; and (3) when pursued simultaneously by a large proportion of firms, the resulting emphasis on higher PPP tends to produce inefficient and bloated market behavior that hold little attraction for young lawyers ${ }^{62}$ and clients. ${ }^{63}$ The market is ripe for an innovator who can tap into this discontent, but change is unlikely to come from firms trying to climb to the top of the Am Law 200 rankings. Part III examines the structural and institutional factors that have produced this paralysis. In turn, we suggest that its antidote is likely found in a new model of mid-sized regional firms, often cobbled together from large firm castaways, that emphasizes cost, collegiality, innovation, collaboration, and shared risks, both within the firm and with clients.

The conundrum described above is the product of a large collective action problem that plagues the modern large U.S. law firm. ${ }^{64}$ If we view the firms' strategic options from the perspective of powerful rainmaking partners, who are necessary for the survival of the firm, the convergence on the premium-work/ large geographic platform business model makes sense. The firm essentially commits to hiring more lawyers with lucrative books of business in complementary practice areas, which in theory will produce a larger and less diluted profit pool. The larger geographic platform, often achieved through merger or hiring of lateral partners for a new branch office, makes it less likely that a client will hire a competing national law firm as the clients' legal and business needs span a larger geographic area. ${ }^{65}$

Although this lateral hiring and geographic expansion may enable powerful lawyers in the firms to strengthen their individual practices, the resulting firms are not necessarily stronger institutions. They are too large and too dispersed to be governed by informal norms of cooperation, trust, and shared risks and rewards; ${ }^{66}$ further, the heavy reliance on laterals undermines or dilutes the sense

62. See, e.g., Mission Statement, Building a Better Legal Profession, available at http://www.betterlegal profession.org/mission.php (grassroots organization of law schools "that seeks market-based workplace reforms in large private law firms" and is "working to ensure that practicing law does not mean giving up a commitment to family, community, and dedicated service to clients").

63. See William D. Henderson, Are We Selling Results or Résumés: The Underexplored Linkage between Human Resource Strategies and Firm-Specific Capital, Indiana University Legal Studies Working Paper No. 105 (April 2008), at 5.7 (documenting and discussing client discontent), available at http://ssm.com/ abstract $=1121238$.

64. Here, we distinguish the majority of U.S. law firms that adopted an eat-what-you-kill remuneration system from their British counterparts that have built global law firms based upon a single-tier lockstep model. For an elegant explication of the British approach, see Angel, supra note 61 (chairman of Linklaters discussing common principles of U.K. global law firms, including the importance of lockstep for maintaining a focus on client service).

65. As noted earlier, the competition for lateral talent occurs on an intensely local level. See supra notes $18-19$, and accompanying text (reporting that $95.7 \%$ of lateral movement is within the same metropolitan area).

66. See earlier discussion of Dunbar number, supra, notes $2-3$, and accompanying text. 
of shared history and culture among the firms' lawyers ${ }^{67}$ Unlike portable books of business, there is no external market reward for partners who allocate their time and ingenuity for the long term benefit of the firm. At all levels of seniority, lawyers' time horizons begin to shrink. As this "lateral culture" increases within firms, the level of cohesion and cooperation is likely to diminish, thus diluting the level of service than can be provided to very demanding corporate clients. ${ }^{68}$ Thus, ironically, these massive firms are actually vulnerable to other service providers, particular boutique and regional law firms, who offer greater value for the broad middle market. So-called commodity legal work may disparaged by law partners trying to move up in the Am Law rankings; but it currently pays for a substantial portion of overhead at many Am Law 200 firms. ${ }^{69}$

The fundamental instability of many large U.S. law firms is evidenced by the large number of Am Law 200 firms in recent years that have collapsed or been wholly absorbed, rather than merged, into other large firms. Not counting Heller Ehrman, ${ }^{70}$ Thelen Reid, ${ }^{71}$ Thacher Proffitt, ${ }^{72}$ and Wolf Block, ${ }^{73}$ which were all large firms with $100+$ years of history that went out of business in late 2008 or early 2009, the ILI lateral dataset contains movements based on the dissolutions of the following Am Law 200 firms: Altheimer \& Gray (headquartered in Chicago), Arter Hadden (Cleveland), Battle Fowler (New York City), Brobeck, Phleger \& Harrison (San Francisco), Coudert Brothers (New York City), Graham \& James (San Francisco), Jenkins \& Gilchrist (Dallas), Pennie \& Edmonds (New York City), and Testa, Hurwitz \& Thibeault (Boston). ${ }^{74}$ For the Am Law 200, this is roughly a six percent mortality rate over a nine-year period. And by all indications, we are currently headed into a serious economic downturn, which could produce a major spike in law firm failures before the end of the decade.

Although it is possible to identify strategic mistakes in the firms that have imploded in recent years, our primary thesis is that the structural problems that

67. According to a recent report jointly authored by Hildebrandt International and Citi Private Bank, the typical large firm has $52 \%$ "home-grown" partners versus $48 \%$ lateral; the number of laterals is higher at many firms. See Client Advisory, supra note 35, at 5-8 \& chart 5.

68. See Angel, supra note 61, at 204-08 (discussing importance of team work and collaboration, which is reinforced by lockstep remuneration, to "maintain focus on target work and clients").

69. See supra, note 48 , and accompanying text.

70. See Drew Combs, Why Heller Died, AM. LAw., Nov. 2008 (discussing details of firms collapse).

71. See Niraj Chokshi \& Petra Pasternak, Thelen Reid Launches Dissolution Vote, Nixon Peabody Launches Offers, RECORDER, Oct. 29, 2008 (discussing dissolution of 400-lawyer firm and that approximately 60 would lateral into Nixon Peabody).

72. See Nate Raymond, How Thacher Proffitt Came to an End, AM. LAw. DaIly, Dec. 22, 2008 (discussing details of how 160 year old firm decided to close its doors), available at http://amlawdaily.typepad.com/ amlawdaily/2008/12/how-thacher-proffitt-came-to-an-end.html.

73. See Gina Passarella, Wolf Block to Close Its Doors, LeGal InTELligencer, Mar. 23, 2009 (reporting on partnership's decision to dissolve the firm).

74. See also Hildebrandi International, Anatomy of Law Firm Failures (2008) (reviewing names of highprofile law firm failures in recent years and referring to company's 2004 study), available at http://www. hildebrandt.com/Documents.aspx?Doc_ID $=2750$. 
plagued these firms are actually endemic to many (and perhaps most) Am Law 200 firms. Indeed, one of the fundamental ironies of the convergence on a single business model, and the instability it produces, is that it flows from an inherently conservative business impulse. Thirty years ago, virtually all firms that later became part of the Am Law 200 were all dominant firms within regional markets. ${ }^{75}$ As noted elsewhere, the history and self-image of these firms is one of "white shoe" establishment and eliteness. ${ }^{76}$ Because this business model has delivered uninterrupted financial prosperity for several decades, it is not surprising that most law firm partners are individually and collectively reluctant to switch to something new and untested. ${ }^{77}$

That said, the pitfalls of staying the course can be readily identified. Because the profitability of these firms is built upon a partner/associate leverage model, each firm must continue to offer the prize of partnership (equity and nonequity) to attract and retain high quality associate lawyers. ${ }^{78}$ In turn, the promotion of more partners-i.e., greater than the retirement rate-requires the hiring of more lawyers to maintain the desired leverage. Historically, these firms have hired national law school graduates or top graduates of regional law schools. And these credentials comport with the pervasive strategy of attracting more high-end, price insensitive work. Yet, with so many firms converging on a similar business model, the demand for elite law school graduates has outstripped supply. ${ }^{79}$ Further, the ensuing associate salary wars have produced cost structures for entry level lawyers that many clients are no longer willing to absorb. ${ }^{80}$

Despite the high salaries and large bonuses paid by Am Law 200 firms, there is evidence of a souring relationship between partners and associates. Associate attrition is too high during good times; ${ }^{81}$ and during the current bad times, it is

75. See Galanter \& Henderson, The Elastic Toumament, supra note 18 , at $1888-89$ \& tbl. 1 (presenting data on the large shift from regional to national competition among large U.S. law firms).

76. See Henderson, supra note 63, at 14. See also Jack Ladinsky, Careers of Lawyers, Law Practice, and Legal Institutions, 28 AM. Soc. Rev. 47, 49 (1963) (in a study of lawyers in metropolitan Detroit, circa 1960, finding that $73 \%$ of Detroit lawyers working in law firms-i.e, not in solo practice-went to one of five national schools: Harvard, Yale, Columbia, Chicago, or University of Michigan).

77. Prosperity, it turns out, can make it impossible for established businesses to adapt to changing marketing condition, thus leading to collapse of seemingly invulnerable enterprises. See generally CLAYTON M. Christiansen, The Innovator's Dilemma: When New Technologies Cause Great Firms to Fall (1997).

78. See Marc Galanter \& Thomas Palay, Tournament of Lawyers: The Transformation of the Big LAW FIRM 99-102 (1991) (discussing inexorable growth dynamics of the "promotion to partnership tournament"); Galanter \& Henderson, The Elastic Tournament, supra note 18, at 1883-84 \& fig. 5 (reviewing growth of NLJ 250 partnerships from 1978 to 2006 and noting that "in the aggregate the predicted pattern of upward growth appears to hold true").

79. See William D. Henderson \& Andrew P. Morriss, What Rankings Don't Say About Costly Choices, NAT'L L.J., Apr. 14, 2008, at 2 (presenting NLJ 250 hiring data for 2005 to 2007 and noting a doubling down on Top 20 law school that accompanied rise in entry level salaries from $\$ 125,000$ to $\$ 160,000$ ).

80. See Henderson, supra note 63, at $2 \mathrm{n.7}$ (collecting numerous legal press accounts discussing reluctance of corporate clients to pay for any first or second year lawyers assigned to their matters).

81. See, e.g., DiPietro, supra note 37, at 44 (reporting figures from NALP that "firms lose 80 percent of law school hires within five years"); Susan Saab Fortney, Soul for Sale: An Empirical Study of Associate 
virtually non-existent. ${ }^{82}$ The increased reliance on lateral hiring undercuts the perception by associates that they are being groomed for partnership. ${ }^{83}$ Increased leverage and de-equitization, which are strategies purportedly necessary to increase profitability and thus remain competitive in the market for lateral partners, ${ }^{84}$ tarnish and dilute the proverbial "brass ring" of partnership. Large law firm managers are quick to conclude that their labor force problems are the result of the shifting attitudes of Millennialists, who are now entering the legal workforce ${ }^{85}$ But over the last several decades, the rapidly growing economic rewards of equity partnership have been substantially offset by the grueling hours required to maintain one's position in the firm. ${ }^{86}$

Many young lawyers may have no interest in a long term future in large corporate law firms, yet there is compelling economic logic that undergirds this system. Elite law school graduates have the most options upon graduation, but they also have the most law school debt. ${ }^{87}$ Large firms have thus become the primary vehicle for paying down student loans and generating attractive outplacement options for future non-law firm employment. But it is unclear whether this approach makes sound business sense for corporate lạw firms.

Stated another way, are credentials more important to the business model than bona fide interest in corporate law and a motivation to succeed within the organization? Industrial psychologists have studied the gap between aptitude and job performance, and a key explanatory variable is employee motivation. ${ }^{88}$ Yet,

Satisfaction, Law Firm Culture, and the Effects of Billable Hour Requirements, 69 UMKC L. REV. 239, 283-84 (2000) (collecting sources that suggest higher associate turnover in recent years, primarily due to higher work demands).

82. See, e.g., Bnuce MacEwen, What's Your Associate Attrition Lately, ADAM SMITH EsQ., Dec. 8, 2008 (discussing vagaries of associate attrition), available at http://www.bmacewen.com/blog/archives/2008/12/ whats_your_attrition_rate.html.

83. See, e.g., DiPietro, supra note 37 , at 44 (noting that "increasing reliance on lateral hires send a discouraging message" to associates); Tom Schoenberg, A Newcomer Moves Up, LEGal TIMES, Sept. 29, 1979 (discussing the lateral partner hiring strategy of Swidler Berlin and how "its associates often seem to have been left behind" as measured by the firm's very low internal promotion rate).

84. See supra, note 30 (collecting sources on relationship between lateral hiring and PPP).

85. See, e.g., Marci Krufka, The Young \& the Restless, LAW PRAC., July/Aug. 2004, at 48 ("Many partners ... are unsure about—even frustrated by-the new brand of associates.").

86. See Kimberly Kirkland, Ethics in Large Law Firms: The Principle of Pragmatism, 35 U. MEM. L. REV. $631,680-83$ (2005) (qualitative study of large law firms in which associates learried that "[y]ou can't say no" and partners observed that "the hours don't get better for partners; partners have even more pressure than associates do"). See also Kenneth G. Dau-Schmidt et al., Gender and the Legal Profession: The Michigan Alumni Data Set 1967-2000 19-20 tbls. D1(5) \& D1(15), 24-25 tbls.E1(5) \& E2(15) (Sept. 27, 2007), available at $\mathrm{http}: / / \mathrm{ssrn} . \mathrm{com} / \mathrm{abstract}=1017362$ (showing that average hours worked per year for Michigan Law graduates five years out has increased 143 hours per year for men and 88 hours per year for women).

87. See Henderson \& Morriss, supra note 79 (presenting evidence that graduates of Top 14 law schools have, on average $\$ 98,746$ in law school debt, which is $\$ 20,000$ or more than graduates of lower ranked schools).

88. See, e.g., Ute-Christine Klehe \& Neil Anderson, The Prediction of Typical and Maximum Performance in Employee Selections, in The Handbook of Personnel Selection (Arne Evers, Neil Anderson, \& Olga Voskuijl, eds., 2005) (noting that job performance is "generally conceptualized as a function of ability and motivation" and reviewing literature and results of empirical studies). 
because most law firm partners are sensitive to issues of pedigree and how their firms may be viewed by clients or prospective lateral partners, the graduates of so-called national law schools are (or were, until the current downturn) virtually guaranteed a job at an Am Law 200 law firm. And at regional schools, the interviewing criteria of large firms are based on rigid GPA cutoffs. To date, the large law firm sector has been reluctant to follow private industry in the use of psychological testing to screen candidate for values, preferences, and personality attributes. ${ }^{89}$ The implicit assumption, it would seem, is that credentials are more important than motivation and organization fit. Yet, the end result is a high cost, high attrition model in which partners read snarky comments about their firm on the "Above the Law" website ${ }^{90}$ and clients proclaim they are no longer willing to have first or second year associates working on their matters. ${ }^{91}$ These dynamics do nothing to increase the prestige of the legal profession.

For the last several decades, virtually all large law firms have adopted some variant of the promotion to partnership tournament. Commentators often refer to this model as the "Cravath system" because of its creation and refinement at the New York law firm of Cravath, Swaine, \& Moore during the early 20th century. ${ }^{92}$ Yet, a description of the Cravath system in Robert Swaine's History of the Cravath Firm, ${ }^{93}$ which was published in 1948, contains an elegant and compact business logic that was designed to create and maintain a law firm that provided impeccable quality and cost-effective service to clients. Partners and associates, in turn, were made better off because the superior service bonded clients to the firm and generated attractive outplacement option for associates who could not be offered partnership. ${ }^{94}$

When analyzed against the recruitment models of today's elite firms, the coherence of the original Cravath system is striking. Under the system

\footnotetext{
89. See, e.g., Toddi Gutner, Applicants' Personalities Put to the Test, WALL ST. J., Aug. 26, 2008, at D4 (reporting that "more than $80 \%$ of midsize and large companies use personality and ability assessments for entry and midlevel positions as either pre-employment or new-employee orientation tools"). But see Elizabeth Goldberg, Is This Any Way to Recruit Associates?, AM. LAw., Aug. 2007 (reporting that Dechert uses personality assessment for professional staff but not for lawyer "for fear it would repel applicants" but that at least one 75-lawyer firm, Sandberg Phoenix \& von Gontard, had committed to using personality tests). In a recent conversation with the director of career services at a regional West Coast law school, one of the authors (Henderson) was told that one Am Law 200 firm requires personality assessments of all Southwestern students offered a callback.

90. See comment thread for virtually any blog post on a specific law firm. The URL for Above the Law is www.abovethelaw.com.

91. See sources cited in note 80 .

92. See Galanter \& PALAY, supra note 78, at 9-10 (1991) (discussing creation and influence of the "Cravath system"); MiLton C. REGAN, JR, EAT What You KILL 20-23 (2004) (discussing origins and influence of the Cravath firm, which "provided a structure whose influence persists to this day").

93. See Robert T. Swaine, The Cravath Firm and Its Predecessors, 1819-1948 Vol. I-ПII (1948).

94. For a detailed discussion of the Cravath system, see William Henderson, Part II: How Most Law Firms Misapply the "Cravath System", LEGAL. PROF. BLOG, July 29, 2008, available at http://lawprofessors.typepad. com/legal_profession/2008/07/part-ii-how-mos.html.
} 
implemented by Paul Cravath, young lawyers were hired directly out of law school and placed on a salary in order to obtain their undivided attention. ${ }^{95}$ Thereafter, associates commenced a process of training that was designed to produce lawyers who possessed the skills to ascend to partnership.

Cravath preferred that men should not specialize in such branches of the law as real estate or administration of estates or, later, taxation, until they had attained a general experience over several years. This objective required that a man should not be confined to the work of one client or be assigned to one partner for any undue length of time.

At the outset of the practice Cravath men are not thrown into deep water and told to swim; rather, they are taken into the shallow water and carefully taught strokes .... Under the "Cravath system" a young man watches his senior break a large problem down into its component parts, is given one of the small parts and does thoroughly and exhaustively the part assigned to him-a process impracticable in the handling of small routine matters. Cravath believed that a man who learns to analyze the component parts of a large problem involving complicated facts, and to do each detailed part well, becomes a better lawyer faster than the man who is not taught in such detail. ${ }^{96}$

As the professional competencies of associates grew, their level of responsibility increased. Ideally, these competencies included the ability to effectively delegate, supervise, and train other lawyers. Swaine observed,

The art of delegation in the practice of the law is difficult, requiring the nicety of balance which many men with fine minds and excellent judgment are unable to attain .... The more nearly he attains the right compromise between [doing all the work himself or turning everything over to an assistant], the greater the amount of effective work a man can turn out, and hence the greater his value to the firm. ${ }^{97}$

Obviously, the Cravath system as conceived by Paul Cravath envisioned a process that spanned several years. Therefore, "[m]en who are willing to stay only a year or two are not desired, for the 'Cravath system' cannot train a man in that short time. They are expected to remain as long, but only as long, as they are growing in responsibility." ${ }^{98}$ In today's high attrition environment, this temporal component has been completely disrupted at most firms.

Although the Cravath system was developed in an era when lateral movement was rare, its underlying business logic required the creation of home-grown

95. See SwAINE, supra note 93, at vol. II, p. 6 ("Cravath could not tolerate the inefficiency and divided loyalty implicit in such an arrangement .... [E]very associate, including the man fresh from law school, was put on a salary.").

96. Id. at vol. II, p. 4.

97. Id. at vol. II, pp. 5-6.

98. Id. at vol. II, p. 7. 
partners. Paul Cravath had an explicit "office policy of filling advanced positions from the ranks of young men who enter the office as beginners." Cravath was aware of the dangers of inbreeding, he "insisted that new partners should be chosen from within the office, unless special requirements otherwise compelled. Young partners and young associates are seldom subjected to the discouragement of seeing someone come in over them from the outside."100 Under the Cravath system, reliance on outside lawyers for business generation was unnecessary because "[a]ll the business in the office must be firm business. ... The problem of the firm is to do effectively the business that comes to it; by so doing that business, more comes in." 101 As a result, "business-getting ability is not a factor in the advancement of a man within the office at any level, except in so far as that ability arises out of competence in doing law work..."102 Eventually, the lockstep system of partnership compensation, for which the Cravath firm is known, locked-in a system of incentives that encouraged cooperation, trust, and a long term time horizon for partners. ${ }^{103}$

By comparison to the thoughtful business logic of the original Cravath system, the present convergence on a single large firm business model appears disjointed and nonsensical. In reality, there is not enough premium, "bet-the-company" work for all the Am Law 200 firms who have targeted this market. Although some firms will successfully occupy this niche in the years to come, others will not. One of us has argued elsewhere that there is a lot of money to be made by focusing on the application of business processes and knowledge management to broad middle market of legal work. ${ }^{104}$ Yet, this requires a consensus among partners to adopt a longer time horizon and retain earnings (which are post-tax!) for investment back into the firm. In a large, geographically dispersed law firm, this outcome is unlikely. And frankly, the firm's largest rainmakers, who are in their peak earning years and probably have (like the rest of us) flagging retirement accounts, are unlikely to go along. And without them, the firms may not survive. Others, sensing the limitations of their own firms, will lateral into larger firms that are more likely to make the cut in the years to come.

It seems likely that a new equilibrium will be reached not by Am Law 200 firms reinventing themselves, but through a process of merger, consolidation, and law firm dissolutions. ${ }^{105}$ Innovation is likely to come from the many young

99. Id. at vol. II, p. 5.

100. Id. at vol. $\mathrm{U}, \mathrm{p} .8$.

101. Id. at vol. II, p. 9.

102. Id. at vol. II, p. 9.

103. Paul C. Saunders, When Compensation Creates Culture, 19 GEO. J. LEGAL ETHICs 295, $296-97$ (2006) (Cravath partner discussing cultural benefits of firm's lockstep compensation system and opining that eat-what-you-kill undermines "collegiality and partnership" and may even create an unethical culture). $C f$. Angel, supra note 61, at 204-05 (discussing cultural benefits of lockstep for perpetuating firmwide goals).

104. See Henderson, supra note 63 , at $22-24$.

105. This is bad news for law firm consultants. The best they can do is broker mergers. 
partners and associates who are affected by this process and have contacts with major corporate clients. Smaller firms staffed by lawyers with sophisticated work experience can escape the inflated cost structure of large law firms and focus anew on clients' desire for more predictable, cost-effective service, including a full-scale migration away from the inefficiencies of hourly billing. Smaller firms owned by young, hungry, and innovative partners could quickly merge into mid-size firms that have the economies of scale and scope to compete with the remaining Am Law 200 firms on the basis of quality. This will speed up the cycle of merger, consolidation, and major law firm failures. The paradigm shift could happen rather quickly. ${ }^{106}$

\section{CONCLUSION}

In this study, we have relied on a broad array of data to identify several trends and patterns affecting large U.S. law firms during the 2000 to 2007 time period. Overall, law firms in the Am Law 200 have become bigger (33.8\% more lawyers), more leveraged (an additional .54 lawyers per equity partner), and more geographically dispersed. During this eight year span, profits per partners at virtually all firms have gone up faster than revenues, albeit at differential rates depending upon a firm's size, reputational endowment, practice areas, and geographic platform.

Yet, when the Am Law 200 is analyzed based on lateral movement, the data reveal a difficult conundrum: lateral movement is greatest among firms with mid-range profits but consistently low among firms with the highest profitability. In pursuit of higher profits-presumably to attract and retain lawyers with valuable books of business-a large proportion of middle-profitability firms have aggressively pursued business strategies, such as higher leverage and rapid geographic expansion, that are unsustainable, inflate a firm's cost structure, and/or create environments in which lawyers are more reluctant to share risk. Partners who have worked in large law firms for 25 or 30 years may not fully appreciate the fact that the rules and payoffs of the promotion to partnership tournament have changed; and that the incoming generation of lawyers is not necessarily impressed by the career path being offered to them. Further, clients are rebelling at billing rates that go up faster than the underlying quality or value of legal services being rendered.

Finally, an analysis of lateral movement by practice areas suggests that large U.S. firms are in the process of differentiating themselves based upon the type of practitioners they are able to attract and retain at their firms. Based on profits per partner of firm left versus firm joined, or percentage of lawyers joining or leaving

\footnotetext{
106. The best historical analogy from the law firm world is the rise of the elite Jewish law firm, which used proxy battle and hostile takeover work to eventually eat away at the core business of elite "white shoe" Wall Street firms. See Eli Wald, The Rise and Fall of the WASP and Jewish Law Firms, 60 STAN. L. REv. 1803 (2008).
} 
the Am Law 200, large price differentials have emerged among lawyers in more lucrative specialties (e.g., capital markets, private equity, white collar crime, securities enforcement) and so-called commodity areas (e.g., regulatory compliance, labor \& employment, trust \& estates, real estate-public/ project finance). Because so many Am Law 200 firms have been focused on the former rather than the latter practice areas-primarily because that is what appeals to the most powerful partners in the firm-it is likely that we may observe an overcapacity that will undermine the financial stability of a large number of firms. For better or worse, this dynamic props open the door to a new wave of boutique and regional law firms with a lower cost-structure and a more innovative, cooperative, and client-centric ethos. So goes the creative destruction of capitalism.

APPENDIX A

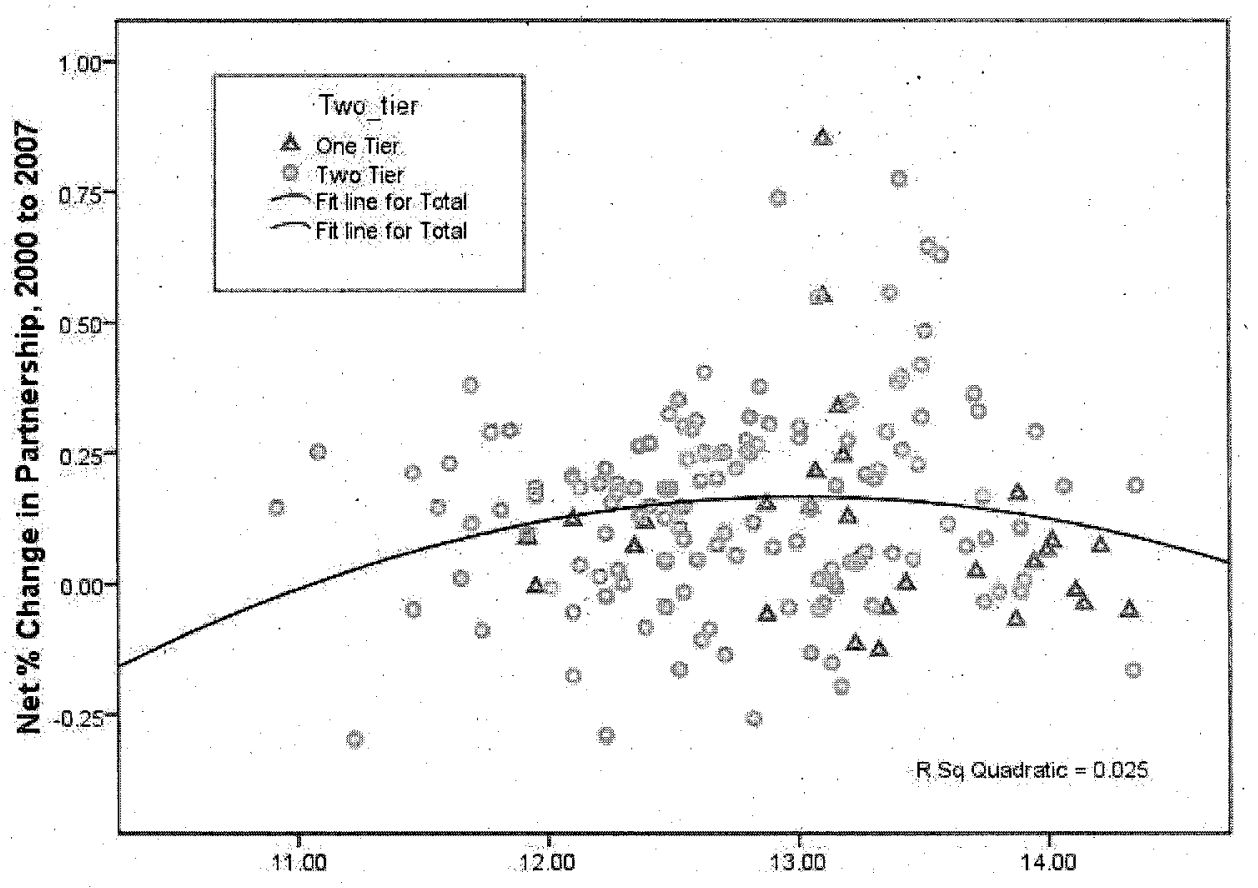

Natural Log of Change in PPP, 2000 to 2007 
APPENDIX B

\begin{tabular}{|c|c|c|c|c|c|}
\hline Category & Variable & $\boldsymbol{\beta}$ & $\begin{array}{c}\text { Std. } \\
\text { Error }\end{array}$ & $\begin{array}{l}\text { Std. } \\
\text { Beta }\end{array}$ & Sig. \\
\hline & (Constant) & 12.471 & 0.028 & & 0.000 \\
\hline \multirow[t]{7}{*}{ Year } & Year 2001 & 0.004 & 0.027 & 0.003 & 0.876 \\
\hline & Year 2002 & 0.077 & 0.027 & 0.057 & 0.005 \\
\hline & Year 2003 & 0.139 & 0.027 & 0.106 & 0.000 \\
\hline & Year 2004 & 0.288 & 0.027 & 0.231 & 0.000 \\
\hline & Year 2005 & 0.298 & 0.027 & 0.242 & 0.000 \\
\hline & Year 2006 & 0.391 & 0.027 & 0.288 & 0.000 \\
\hline & Year 2007 & 0.424 & 0.027 & 0.354 & 0.000 \\
\hline \multirow[t]{7}{*}{ Regional Market } & Joined DC Office & 0.141 & 0.009 & 0.119 & 0.000 \\
\hline & Joined NYC Office & 0.165 & 0.008 & 0.147 & 0.000 \\
\hline & Joined Chicago Office & 0.023 & 0.011 & 0.013 & 0.043 \\
\hline & Joined San Francisco Office & 0.153 & 0.012 & 0.089 & 0.000 \\
\hline & Joined LA Office & 0.138 & 0.012 & 0.077 & 0.000 \\
\hline & Joined London Office & 0.010 & 0.017 & 0.004 & 0.568 \\
\hline & Other Foreign Office & 0.269 & 0.012 & 0.192 & 0.000 \\
\hline \multirow[t]{7}{*}{ Setting Left } & Federal Prosecutor or DOJ & 0.110 & 0.022 & 0.031 & 0.000 \\
\hline & Other Federal Employment & 0.141 & 0.020 & 0.045 & 0.000 \\
\hline & State Government Employment & 0.043 & 0.028 & 0.009 & 0.124 \\
\hline & Private industry & 0.003 & 0.011 & 0.002 & 0.799 \\
\hline & Am Law 101-200 & 0.025 & 0.066 & 0.021 & 0.701 \\
\hline & Am Law 51-100 & -0.044 & 0.066 & -0.037 & 0.504 \\
\hline & Am Law 50 & 0.163 & 0.009 & 0.114 & 0.000 \\
\hline \multirow[t]{2}{*}{ Firm Joined } & Number of Lawyers (100s) & 0.007 & 0.000 & 0.077 & 0.000 \\
\hline & Leverage & 0.154 & 0.003 & 0.384 & 0.000 \\
\hline \multirow[t]{11}{*}{ Practice Area } & Regulatory & -0.045 & 0.011 & -0.029 & 0.000 \\
\hline & Antitrust & 0.129 & 0.021 & 0.038 & 0.000 \\
\hline & M\&A, Cap. Markets, Private Equity & 0.121 & 0.012 & 0.064 & 0.000 \\
\hline & Intellectual Property & 0.080 & 0.010 & 0.056 & 0.000 \\
\hline & Labor \& Employment & -0.117 & 0.012 & -0.063 & 0.000 \\
\hline & Real Estate, Public/Project Fin. & -0.034 & 0.012 & -0.020 & 0.003 \\
\hline & White Collar \& Sec. Enfor. & 0.151 & 0.022 & 0.042 & 0.000 \\
\hline & Trusts \& Estates & -0.085 & 0.030 & -0.018 & 0.004 \\
\hline & Bankruptcy & 0.062 & 0.018 & 0.022 & 0.001 \\
\hline & Corporate Securities & 0.053 & 0.009 & 0.043 & 0.000 \\
\hline & Other Practice Areas & 0.001 & 0.010 & 0.001 & 0.895 \\
\hline \multirow[t]{2}{*}{ Serial mover } & Second or Third move & 0.001 & 0.010 & 0.000 & 0.938 \\
\hline & $N=13,370$ & \multicolumn{4}{|c|}{ Adj. R-squared $=0.504$} \\
\hline
\end{tabular}

